\title{
Houses of Representatives? Courtyard Sites North of the Polar Circle: Reflections on Communal Organisation from the Late Roman Period to the Viking Age
}

\author{
FRODE IVERSEN*
}

\begin{abstract}
Introduction
THE WORD THING DESCRIBES A legal assembly, and it appears in all the Germanic languages. It has been understood as 'a gathering in a certain place, at a certain time'. The thing is well known in Norway and in Iceland from the 12th and 13th centuries onwards. Norwegian provincial laws, dating back to the 1100 s, indicate that representatives from specific areas met annually at law-things (lagting) that were held at an appointed time and place. How far back these traditions can be traced, and how the thing evolved during the period AD 400-1200 are issues that touch upon some of the fundamental questions about the organisation of law and landscape during the Iron Age and medieval period.

I would like to explore these issues, drawing upon an archaeological source unique to Norway, the so-called courtyard sites. A courtyard site is essentially 'a collection of houseplots set in a semi-circular formation facing a central open space (tún)'. Thirty such sites are known from the west coast of Norway from Agder in the south to Hålogaland in the north (Figure 8.1). The earliest known examples were established in the 1st century $\mathrm{AD}$, and the most recent examples were still in use in the 11th century (e.g. Trøndelag, Figure 8.2). The sites vary in size from up to thirty houseplots,

\footnotetext{
* I would like to thank Alexandra Sanmark, Sarah Semple and Natascha Mehler for discussions and exchange of ideas and Jessica McGraw for translating this chapter. My sincere thanks to Barbara Yorke and Jayne Carroll for critical reading, and comments with regards to this manuscript. I also thank Stuart Brookes, John Baker and Andrew Reynolds for inviting The Assembly Project to participate at the Power and Place conference at UCL Institute of Archaeology, London.

${ }^{1}$ O. S. Johansen and T. Søbstad, 'De nordnorske tunanleggene fra jernalderen', Viking, 41 (1978), 9-56 at 55 .
} 


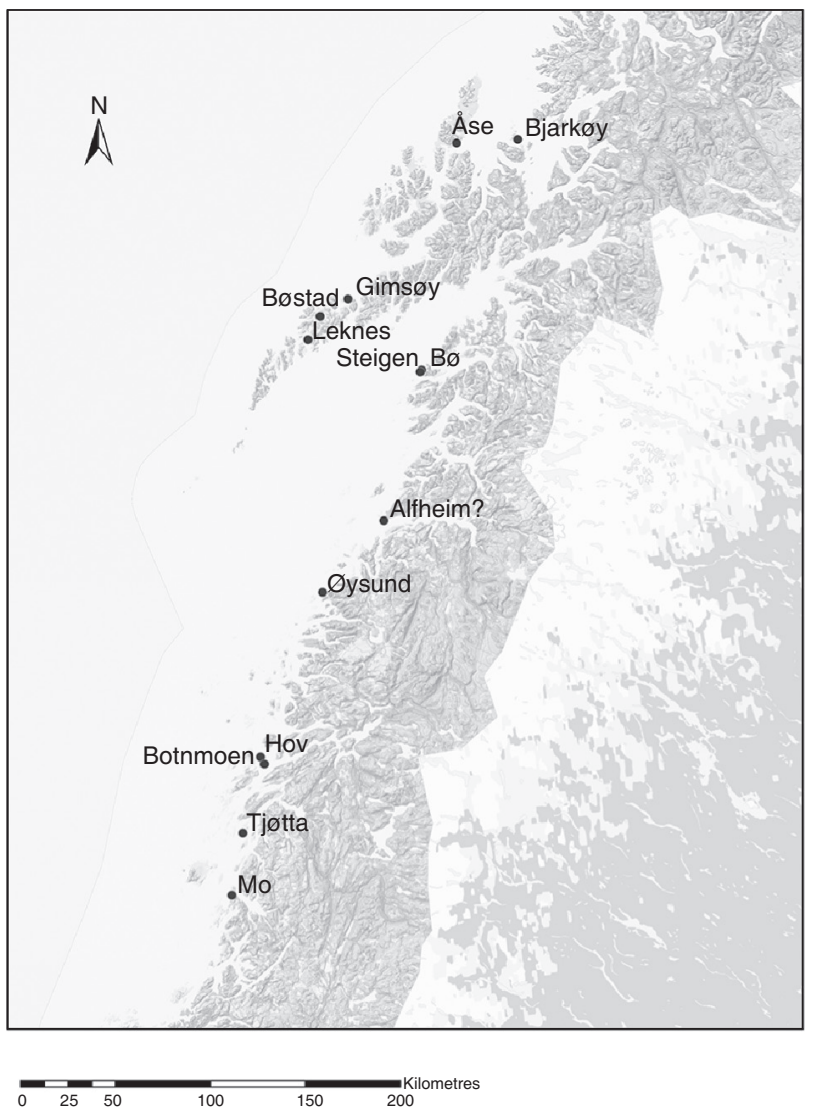

Figure 8.1 Courtyard sites in Hålogaland (Frode Iversen)

for example Dysjane at Jæren in Rogaland, down to minor sites such as Bøstad in Lofoten, which contains only four houseplots. Certain minor sites, with houseplots arranged in parallel lines, have also been proposed as possible courtyard sites. Even so, there is a distinction to be made between large well-organised sites with a central mound, and minor sites without a central mound and symmetrical layout. The larger sites, which in recent times have been interpreted as a form of assembly site, are of special relevance to this chapter. These are located at Bjarkøy, Åse, Leknes and Steigen within the Polar Circle, in Hålogaland (Figure 8.1). There are several questions concerning courtyard sites that remain unresolved: the administrative level(s) at which they functioned; whether they were local assembly units or, more likely, regional; when and why they fell out of use, and whether this could have been caused by the emergence of petty-kingdoms and earldoms, as Inger Storli claims. ${ }^{2}$

2 I. Storli, Hålogaland før rikssamlingen. Politiske prosesser i perioden 200-900 e. Kr, Instituttet for sammenlignende kulturforskning (Oslo, Novus forlag, 2006); I. Storli, "Barbarians" of the North: Reflections on the Establishment of Courtyard Sites in North Norway', Norwegian Archaeological Review, 33.2 (2000), 81-103. 


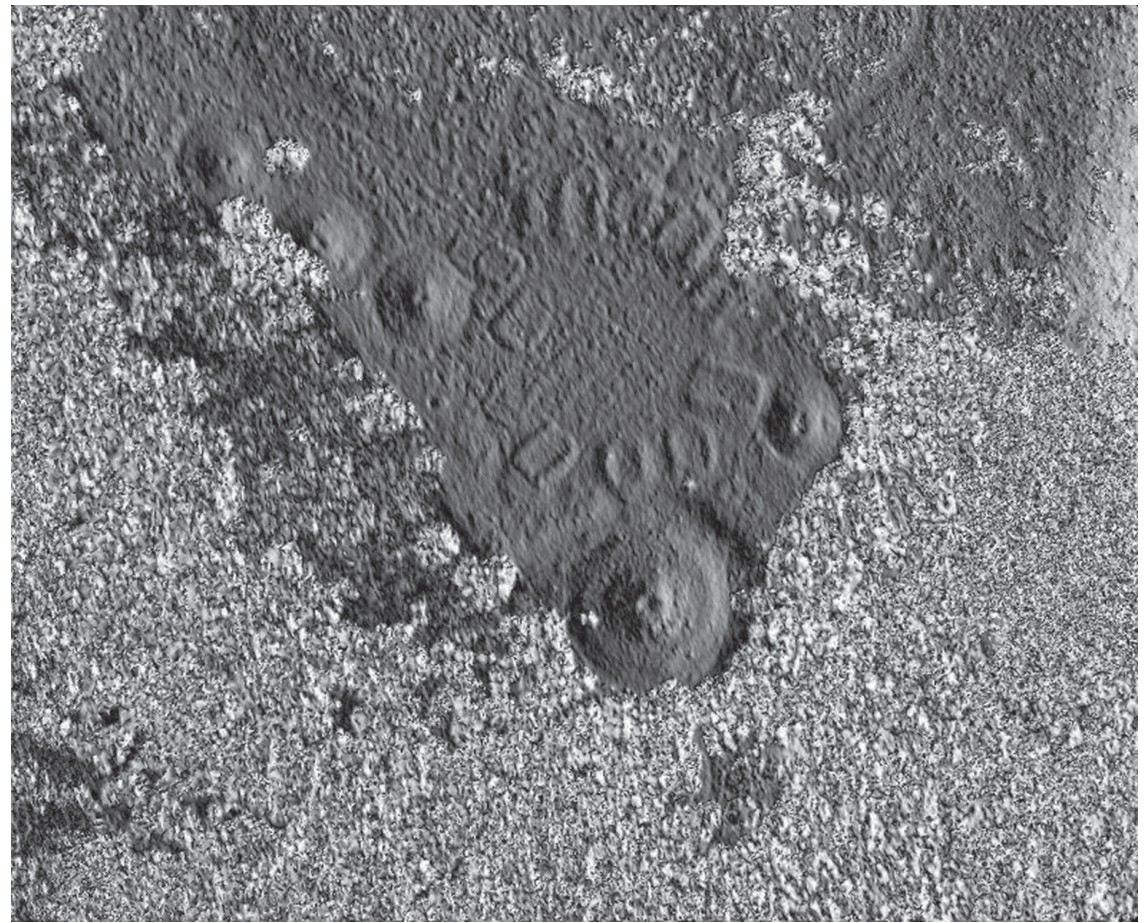

Figure 8.2 LiDAR of the courtyard site at Værem, Grong, Namdalen, north of Trondheim. This site was still in use in the early 9th century (illustration by kind permission, Lars Forseth, NordTrøndelag fylkeskommune)

The Norwegian historian Peter Andreas Munch argued early on that preChristian Norway was organised in geographical units and jurisdictions such as fylker (Old Norse (ON) fylkir, 'folk-lands'), fjerdinger (ON fjórðungr, quarters) and tredinger (ON priðjungr, tripartite, ridings). ${ }^{3}$ Such units are well known in laws and charters from the 1100s onwards. At upper level law-things, hundreds of representatives met annually; for example, until the 17th century 485 representatives from eleven regions met at Frostathing in Trøndelag, and before the mid-12th century, around 400 representatives met at Gulathing at the estuary of Sognefjord. ${ }^{4}$

The question here is whether the courtyard sites were in fact thing-sites which pre-dated the establishment of the larger law-areas known from the 10th century. This could be suggested by, for example, a connection between the number of houseplots in the courtyard sites and the number of administrative units within

${ }^{3}$ P. A. Munch, Historisk-geographisk Beskrivelse over Kongeriget Norge (Noregsveldi) i Middelalderen (Moss, Gram, 1849), p. 13.

${ }^{4}$ K. Helle, Gulatinget og Gulatingslova (Leikanger, Skald/Hovudkomiteen for Gulatinget, 2001);

J. Sandnes and J. R. Hagland (trans.), Frostatingslova, Norrøne bokverk (Oslo, Samlaget, 1994). 
certain regions recognised in later written sources, and a central location within these regions for the courtyard sites. Could the sites indicate the presence of communal institutions based on geographical representation all the way back to the early 1 st millennium $\mathrm{AD}$ ?

The thing, consisting of free-born individuals, has been considered as the communal institution par excellence. ${ }^{5}$ The men who met at representational assemblies were called lagrettemenn (ON logréttumenn, 'lawright-men') or nemdemenn (ON nefndarmenn, 'appointed men'). They were sworn in by the highest judge, the lagmann (ON logmaðr, 'law-man'), and thus authorised as lay judges. In the late Middle Ages, the position of an appointed man was clearly one of high status and was probably for life. ${ }^{6}$ It is unclear what functions the thing fulfilled in Norway and Scandinavia during the Iron Age. I presuppose that early on, the thing had interlaced and embedded functions of a military, cultic and legal character (Figure 8.3); examination of the courtyard sites may throw light on how it changed and evolved with the establishment of petty-kingships from $\mathrm{AD} 600$ onward and the emergence of Christian supra-regional kingdoms in the 10th and 11 th centuries.

\section{Research History}

Interpretations of courtyard sites fall on the whole into two categories: communal functions or accommodation for the followers of chieftains. As early as 1866 , the archaeologist Nicolay Nicolaysen suggested that the large site at Dysjane at Hauge in Jæren could have been a thingplads, with houseplots (tomter af boder). ${ }^{7}$ This view represents the first 'communal' interpretation. During the 1920s and 1930s, Jan Petersen interpreted courtyard sites as rural villages (Figure 8.4). ${ }^{8}$

5 S. Brink, 'Legal Assembly Sites in Early Scandinavia', in A. Pantos and S. Semple (eds), Assembly Places and Practices in Medieval Europe (Dublin, Four Courts Press, 2004), pp. 205-16; A. Bugge, 'Tingsteder, gilder og andre gamle mittpunkter i de norskebygder', Historisk tidsskrift, 5. r. 4 b 1917 (1918), 97-152 and 195-252; S. Imsen, Norsk bondekommunalisme, fra Magnus Lagabøte til Kristian Kvart, vol. 1 (Trondheim, Tapir, 1990); A. Pantos and S. Semple (eds), Assembly Places and Practices in Medieval Europe (Dublin, Four Courts Press, 2004); A. Sanmark, 'The Communal Nature of the Judicial System in Early Medieval Norway', Collegium Medievale, 19 (2006), 31-64; A. Sanmark and S. Semple, 'Places of Assembly: Recent Results from Sweden and England', Fornvännen, 103.4 (2008), 245-59; H. Scledermann, 'Tingsted', in F. Hødnebø (ed.), Kulturhistorisk Leksikon for Nordisk Middelalder 18 (Oslo, Gyldendal, 1974), pp. 373-6; D. Skre, 'The Skiringssal Thing Site pjoðalyng', in D Skre (ed.), Kaupang in Skiringssal, Kaupang Excavation Project Publication Series 1, Norske Oldfunn, 22 (Aarhus, Aarhus University Press, 2007), pp. 385-406; P. Sveaas-Andersen, 'Ting', in F. Hødnebø (ed.), Kulturhistorisk Leksikon for Nordisk Middelalder 18 (Oslo, Gyldendal, 1974), pp. 346-59.

${ }^{6}$ H. D. Bratrein, Karlsøy og Helgøy bygdebok: folkeliv, nceringsliv, samfunnsliv (Hansnes, Karlsøy kommune, 1989).

${ }^{7}$ N. Nicolaysen, Norske fornlevninger. En oplysende fortegnelse over Norges fortidslevninger celdre end reformationen og henførte til hver sit sted (Kristiania, Werner, 1866), p. 301.

8 J. Petersen, 'Leksaren', Viking, 2 (1937/1938), 151-8, at 156-7. 


\section{Time}

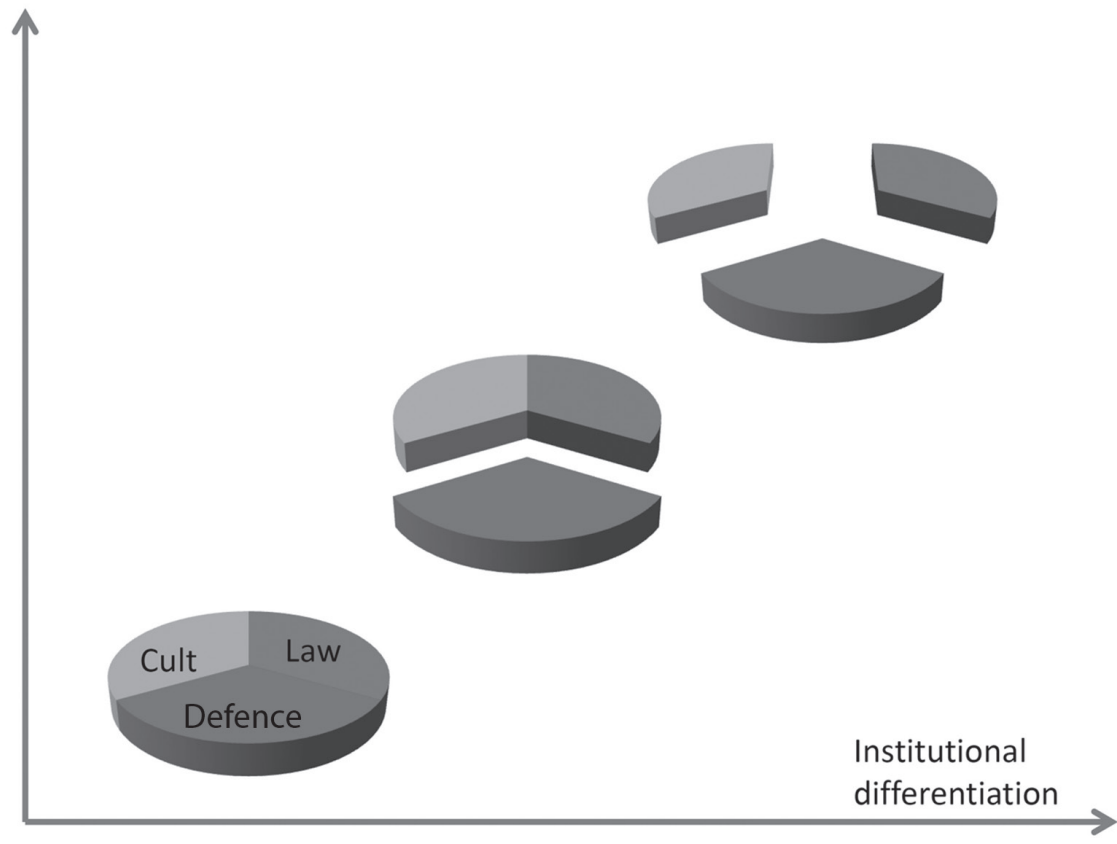

Figure 8.3 Model of the proposed development of the thing AD 400-1200. The three main functions (cultic, military and legal) become separated (Frode Iversen)

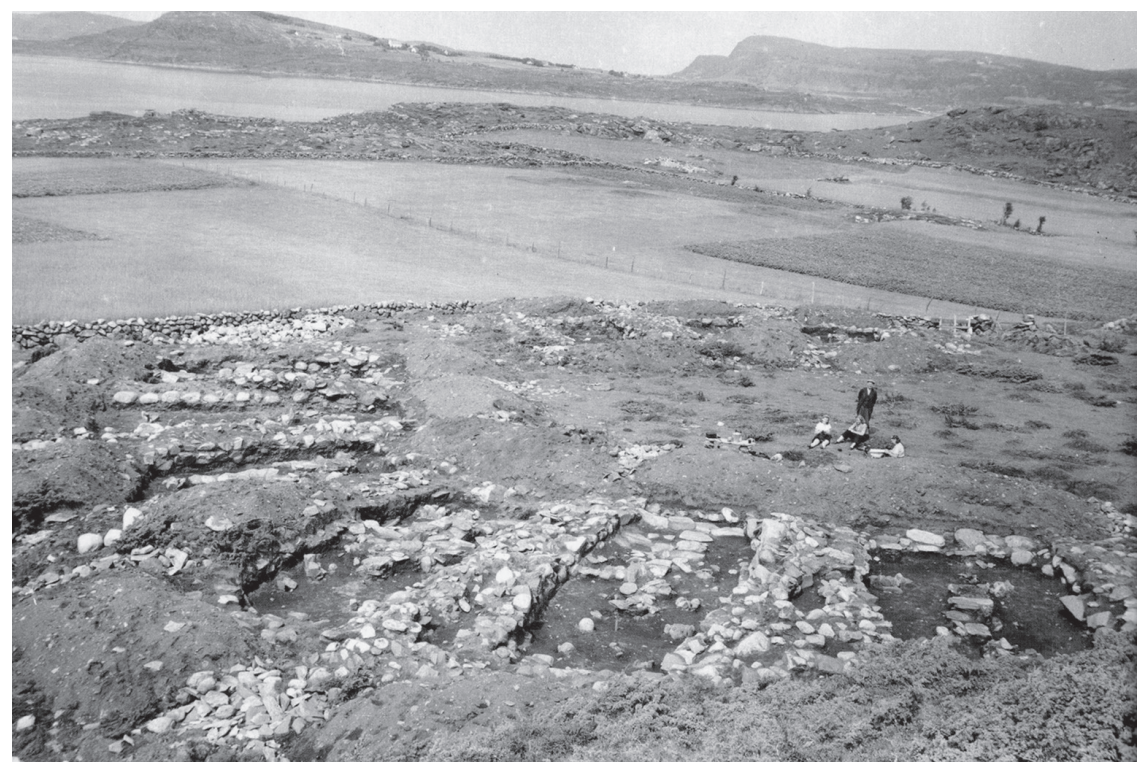

Figure 8.4 The courtyard site at Øygarden, Rogaland, Jan Petersen's excavation, $c .1940$ (Arkeologisk Museum, Stavanger) 
However, pollen analyses do not support the idea of cultivation in the vicinity of these sites, and they are generally located far from arable land. ${ }^{9}$ In the 1950 s, Harald Egenes Lund saw a connection between courtyard sites, rich and impressive burials, and large boathouses..$^{10}$ In his view, the sites were strategically placed and accommodated the chieftain's followers. This was the prevailing interpretation through the 1980s and 1990s, and few maintained the view that these sites were communal structures. ${ }^{11}$

The first systematic overview of material in Northern Norway was conducted by Olav Sverre Johansen and Tom Søbstad in $1978 .{ }^{12}$ They also discussed a possible relationship of the sites to a system of minor chieftainships. Birgitta Berglund interpreted the site of Tjøtta as a chieftain's hall and assembly place for cultic, legal and military purposes. ${ }^{13}$ Important contributions in this period emanated from Johansen, and also from Bergljot Solberg. ${ }^{14}$ Possible cultic aspects have been emphasised by Terje Gansum, who interpreted courtyard sites as ritual assembly sites in connection to warfare. ${ }^{15}$ Niall J. Armstrong is more isolated in his interpretation of courtyard sites as emulations of Roman amphitheatres that functioned as cultural structures for mercenary returnees. ${ }^{16}$ In a recent work, Armstrong stressed their functions in rites of passage. ${ }^{17}$ The Polish archaeologist Przemisław Urbańczyk has given the sites a possible ethnic dimension, connected

${ }^{9}$ B. Berglund, Tjøtta-riket - en arkeologisk undersøkelse av maktforhold og sentrumsdannelser på Helgelandskysten fra Kr. $f$. til 1700 e. Kr. (Trondheim, UNIT, Vitenskapsmuseet, Fakultet for arkeologi og kulturhistorie, Arkeologisk avdeling, 1995); A. B. Olsen, 'Courtyard Sites in Western Norway: Central Assembly Places and Judicial Institutions in the Late Iron Age', in M. H. Eriksen et al. (eds), Viking Worlds: Things, Spaces and Movement (Oxford, Oxbow, 2014), pp. 43-55; B. Solberg, 'Courtyard Sites North of the Polar Circle: Reflections of Power in the Late Roman and Migration Period', in B. Hårdh and L. Larsson (eds), Central Places in the Migration and Merovingian Periods, Papers from the 52nd Sachsensymposium (Stockholm, Almquist and Wiksell, 2002), pp. 219-29.

${ }^{10}$ H. E. Lund, 'Håløygske høvdingeseter fra jernalderen', Stavanger Museums Arbok, 65 (1955), 101-7; H. E. Lund, 'Håløygske høvdingeseter og tunanlegg fra eldre og yngre jernalder', Håløygminne, 10 (1959), 244-9; H. E. Lund, 'Håløygske høvdingegårder og tunanlegg av Steigen-typen fra eldre og yngre jernalder. "Valhall med de mange dører", Norsk Tidsskrift for sprogvitenskap, 20 (1965), 287-325.

${ }^{11}$ O. Grimm, Roman Period Court Sites in South-Western Norway: A Social Organisation in an International Perspective, AmS-skrifter, 22 (Stavanger, Museum of Archaeology, University of Stavanger, 2010), p. 12; B. Magnus and B. Myhre, Forhistorien - fra jegergruper til høvdingsamfunn: Norges historie 1 (Oslo, Cappelen, 1976), pp. 265, 315, 380.

12 Johansen and Søbstad, 'De nordnorske tunanleggene'.

13 Berglund, Tjøtta-riket, pp. 48-9, 342-5.

${ }^{14}$ O. S. Johansen, 'Vikingene lengst i nord. Håløygske høvdingsenter i Nord-Norge', in H. Bekker-Nielsen and H. F. Nielsen (eds), Syvende tvcerfaglige vikingsymposium (Odense, Hikuin and Afdeling for Middelalder arkæologi, 1988), pp. 20-46; Solberg, Courtyard Sites.

15 T. Gansum, 'Etterord', in J. Illkjær, Den første Norgeshistorien-Illerupfunnet: Ny innsikt i skandinavisk romertid (Tønsberg, Kulturhistorisk Forlag, 2000), pp. 148-69.

${ }_{16}$ N. J. Armstrong, 'Tunanlegg og amfiteatre. En hypotese om tunanleggenes opprinnelse', Primitive tider, 3 (2000), 102-18.

${ }^{17}$ N. J. Armstrong, 'Becoming People: Early Iron Age Courtyard Sites in Norway as Arenas for Rites de Passage', in G. Lillehammer (ed.), Socialisation: Recent Research on Childhood and Children in the Past: Proceedings from the 2nd International Conference of the Society for the Study of Childhood in the Past in Stavanger, Norway, 28-30th September 2008, AmS-Skrifter 23 (Stavanger, Arkeologisk Museum, 2010), pp. 115-24. 
to an increased exchange of commodities during the Roman period. He has argued that the northern Norwegian sites were located on neutral grounds appropriate for negotiation between the Sámi and the Norse. ${ }^{18}$ Bjørn Myhre, on the other hand, highlighted the similarities, rather than contrasts, between the southern and northern sites. ${ }^{19}$

Morten Olsen was among the first to suggest a revised interpretation of the sites as judicial assembly sites, using those in the Jæren area as examples. He noted their function as communal structures and stressed that the sites can be seen as evidence of socio-political commerce. ${ }^{20}$ Important work has been done by Asle Bruen-Olsen excavating two sites in Western Norway, interpreted as assembly sites. ${ }^{21}$ Oliver Grimm and Frans-Arne Stylegar support these theories to some degree and interpret the courtyard sites as multi-functional. ${ }^{22}$ They suggest that they provided space for a range of activities, such as sports and games, judicial assemblies, diverse rituals and craft production, as well as accommodating the chieftain's followers.

The assembly interpretation has been put forward rigorously by Storli, who in 2006 presented an extensive review of the sites in Hålogaland. With this, she puts the theories of Nicolay Nicolaysen from 1866 back on the research agenda, and argues that the abandonment of courtyard sites was caused by the emergence of larger political units. She views the courtyard sites in Hålogaland as early examples of the thing-booths known from Iceland, ${ }^{23}$ and her article in Norwegian Archaeological Review 2010 resulted in an extensive discussion in the following issue (2011) where, among other things, it was pointed out that her interpretation is largely based on Icelandic analogies, and to a lesser extent on the local

\footnotetext{
18 P. Urbańczyk, Medieval Arctic Norway (Warsaw, Institute of the History of Material Culture, 1992).

19 B. Myhre and I. Øye, Norges landbrukshistorie 1—Jorda blir levevei: 4000 f.Kr.-1350 e.Kr. (Oslo, Norske Samlaget, 2002), pp. 201-7.

${ }^{20}$ M. Olsen, 'Den sosio-politiske organiseringen av Jæren i eldre jernalder. Et tolkningsforsøk med utgangspunkt i skriftlige kilder og tunanleggene' (unpublished master's dissertation, University of Tromsø, 2003), pp. 11, 126-7.

${ }^{21}$ A. B. Olsen, 'Et vikingtids tunanlegg på Hjelle i Stryn. En konservativ institusjon i et konservativt samfunn', in K. A. Bergsvik and A. Engevik (eds), Fra funn til samfunn. Jernaldersstudier tilegnet Bergljot Solberg på 70-årsdagen (Bergen, Arkeologisk institutt, University of Bergen, 2005), pp. 319 54; A. B. Olsen, 'Undersøkelse av et eldre jernalders tunanlegg på Sausjord, Voss, Hordaland—et nytt bidrag til kunnskapen om jernaldersamfunnets sosiale og politiske organisasjon', Viking, 76 (2013), 87-112; Olsen, Courtyard Sites.

${ }^{22}$ O. Grimm and F. A. Stylegar, 'Court Sites in Southwest Norway: Reflection of a Roman Period Political Organisation?', Norwegian Archaeological Review, 37.2 (2004), 111-33.

${ }^{23}$ For Icelandic thing-booths see O. Vésteinsson, 'What Is in a Booth? Material Symbolism at Icelandic Assembly Sites', Journal of the North Atlantic, Special Volume 5 (2013), 111-24; I. Storli, 'Court Sites of Arctic Norway: Remains of Thing Sites and Representations of Political Consolidation Processes in the Northern Germanic World during the First Millennium AD?', Norwegian Archaeological Review, 43.2 (2010), 128-44.
} 
historical source material. ${ }^{24}$ Finally, in recent work I have suggested that the sites held the function of representative things on a regional level. ${ }^{25}$

\section{Method and Material}

My contribution here is to interpret the courtyard sites in an administrative context, investigating the scale and the period of use of these sites, as well as their spatial location in administrative terms. Such an approach has not been applied to these sites before. ${ }^{26}$ In implementing this method, I intend to address the question of whether courtyard sites were houses of representatives. For information about the size of the individual sites, dating and location, I will use the study on Hålogaland, and draw upon the works of Grimm and Stylegar and other publications for individual sites. ${ }^{27}$ The quality of the data from sites in Hålogaland varies and I have therefore focused on a few larger sites that have been well documented and reliably dated. All Carbon-14 ages are calibrated in OxCal v3.10.

There are thirteen courtyard sites within Hålogaland (Figure 8.1), ranging from simple single-row sites with four houseplots (Bøstad, Øysund) to larger horseshoe-shaped courtyards with six to eight houseplots (Gimsøy, Bø). The majority of sites are large oval-shaped units consisting of between twelve and sixteen houseplots (Bjarkøy, Åse, Leknes, Steigen and Tjøtta, and, more uncertainly, Hov, Botnmoen and Mo). Both the dating samples and the archaeological material suggest that some of the sites could have been in continuous use for over 400 years, which is emphasised by the presence of substantial cultural layers, over $1 \mathrm{~m}$ in depth at some of the sites. It is difficult to assess with any degree of certainty the frequency of activity or any seasonal variation in usage over time. Several of the sites are located by boggy and waterlogged areas, which would have frozen

${ }^{24}$ S. Brink et al., Comments on Inger Storli, 'Court Sites of Arctic Norway: Remains of Thing Sites and Representations of Political Consolidation Processes in the Northern Germanic World during the First Millennium AD?', Norwegian Archaeological Review, 43.2, Norwegian Archaeological Review, 44.1 (2011), 89-117.

${ }^{25}$ F. Iversen, 'Om aritmetikk og rettferdighet. Tinget i randen av Europa i jernalderen', in S. H. Gullbekk (ed.), Ja, vi elsker frihet (Oslo, Dreyer Forlag A/S, 2014), pp. 246-56; F. Iversen, 'Community and Society: The Thing at the Edge of Europe', Journal of the North Atlantic, Special Volume 8 (2015), 1-17; F. Iversen, 'Houses of Commons, Houses of Lords? The Thing on the Threshold of Statehood in Rogaland, Western Norway in the Merovingian and Viking Ages', in I. Baug, J. Larsen and S. S. Mygland (eds), UBAS Nordic Middle Ages: Artefacts, Landscapes and Society: Essays in Honour of Ingvild Øye on her 70th Birthday (Bergen, University of Bergen, 2015), pp. 175-92; F. Iversen, 'Hålogaland blir en rettskrets', Heimen, 52.2 (2015), 101-20.

${ }_{26}$ See however Iversen, Om artimetikk and Hålogaland.

${ }^{27}$ Grimm, Roman Period (sites at Jæren); Grimm and Stylegar, Court Sites; Olsen, Den sosio-politiske (sites at Jæren); I. O. Strøm, 'Tunanlegg i Midt-Norge. Med særlig vekt på Væremsanlegget i Namdalen' (unpublished master's thesis, NTNU, Trondheim, 2007) (sites in Trøndelag). Individual sites: K. S. Binns, 'Ringformet tunanlegg—også oppdaget på Mo i Brønnøy', Spor, 2 (1988), 50; K. Kallhovd, 'Den kulturhistoriske orden. En analyse med utgangspunkt i Leksaren' (unpublished master's dissertation, University of Oslo, 1994); L. Stenvik, Skei. Et maktsenter fram fra skyggen, Vitark 2, Acta Archaeologica Nidrosiensia (Trondheim, Vitenskapsmuseet NTNU, 2001); Olsen, Et vikingtids tunanlegg. 
during wintertime. The finding of hearths inside houseplots suggests a need for warmth. A fitting belonging to a sleigh (Tjøtta) and so-called fire-heaps'elevated' cooking pits in cairns visible above snow-level — are further indications of usage during winter. The stratigraphy at Steigen shows alternate inclusions of sand-lenses and bands, which may indicate cycles of usage, where drifts of sand covered the site during short periods of disuse.

Three sites have a main period of use during the late Iron Age: Bjarkøy in Senja, Steigen in Salten and Tjøtta in Helgeland. This is more uncertain for three other sites in Helgeland: Mo, Botnmoen and Hov, where the datings are less reliable. Six other sites indicate a main period of use during the early Iron Age, with one unit located at Helgeland (Øysund) and one in Salten (Bø). In Lofoten and Vesterålen, three places were in use simultaneously: Leknes, Bøstad and Gimsøy. In Omd (Andenes and Senja), Åse was probably in use before the Bjarkøy site.

Four out of thirteen sites in Hålogaland are included in this analysis. Initial excavations were conducted by Lund during the 1940s and 1950s at Tjøtta, Bjarkøy, Bø, Steigen and Leknes. ${ }^{28}$ A smaller excavation at Åse was conducted by Thorleif Sjøvold in 1948-9. ${ }^{29}$ The Hålogaland sites were published in 1978 by Olav Sverre Johansen and Tom Søbstad, which represented a milestone, as both the work by Lund and new radiocarbon dates were made accessible. ${ }^{30}$ Seven sites were reviewed in the publication: Bjarkøy, Steigen, Bø, Leknes, Åse, Gimsøy and Bøstad. The site at Tjøtta was only briefly mentioned, but has since been studied by Birgitta Berglund. ${ }^{31}$ Because of the lack of section drawings in Lund's excavations, it is only partly possible to relate finds and Carbon-14 samples to the correct stratigraphic level.

More recently, four additional sites have been discovered, at Gimsøy, Øysund at Meløy, Mo at Brønnøy, and Hov at Løkta. ${ }^{32}$ During the 1990s, Storli conducted supplementary investigations of several sites in northern Hålogaland. This has provided new dates and documentation of most of the sites there, which I will draw upon. ${ }^{33}$

Several works deal with Norwegian administrative structures in the Middle Ages at a regional and national level, including contributions by Munch, Gustav Storm, Edvard Bull, Gustav Indrebø, Asgaut Steinnes and Audun Dybdahl. ${ }^{34}$

${ }^{28}$ Grimm, Roman Period, p. 53.

${ }_{29}$ T. Sjøvold, ‘Åse-anlegget på Andøya. Et Nord-Norsk tunanlegg fra jernalderen', Acta Borealia, B. Humaniora, 12 (1971), 5-34.

30 Johansen and Søbstad, 'De nordnorske tunanleggene'.

31 Berglund, Tjøtta-riket; B. Wik, Tunanlegget på Tjøtta: en økonomisk og demografisk miljøstudie, Gunneria, 44 (Trondheim, Det Kgl. norske videnskabers selskab, Museet, 1983).

32 Berglund, Tjøtta-riket; Binns, Ringformet tunanlegg; Wik, Tunanlegget på Tjøtta.

33 Storli, Barbarians; Storli, 'Court Sites of Arctic Norway'; Storli, Hålogaland før rikssamlingen.

${ }^{34}$ E. Bull, Leding. Militcer- og finansforfatning I Norge i celdre tid (Kristiania/Copenhagen, Steenske forlag, 1920); A. Dybdahl, 'Fylker og skipreider i Trøndelag', Historisk tidsskrift, 76.2 (1997), 21148; G. Indrebø, Fjordung: granskingar i eldre norsk organisasjons-soge. Bergens museums aarbok, 1 (Bergen, Museum of Bergen, 1936); Munch, Historisk-geographisk; A. Steinnes, Styrings- og rettsskipnad i Sørvest-Noreg i mellomalderen (Oslo, Det norske samlaget, 1974); G. Storm, Monumenta 


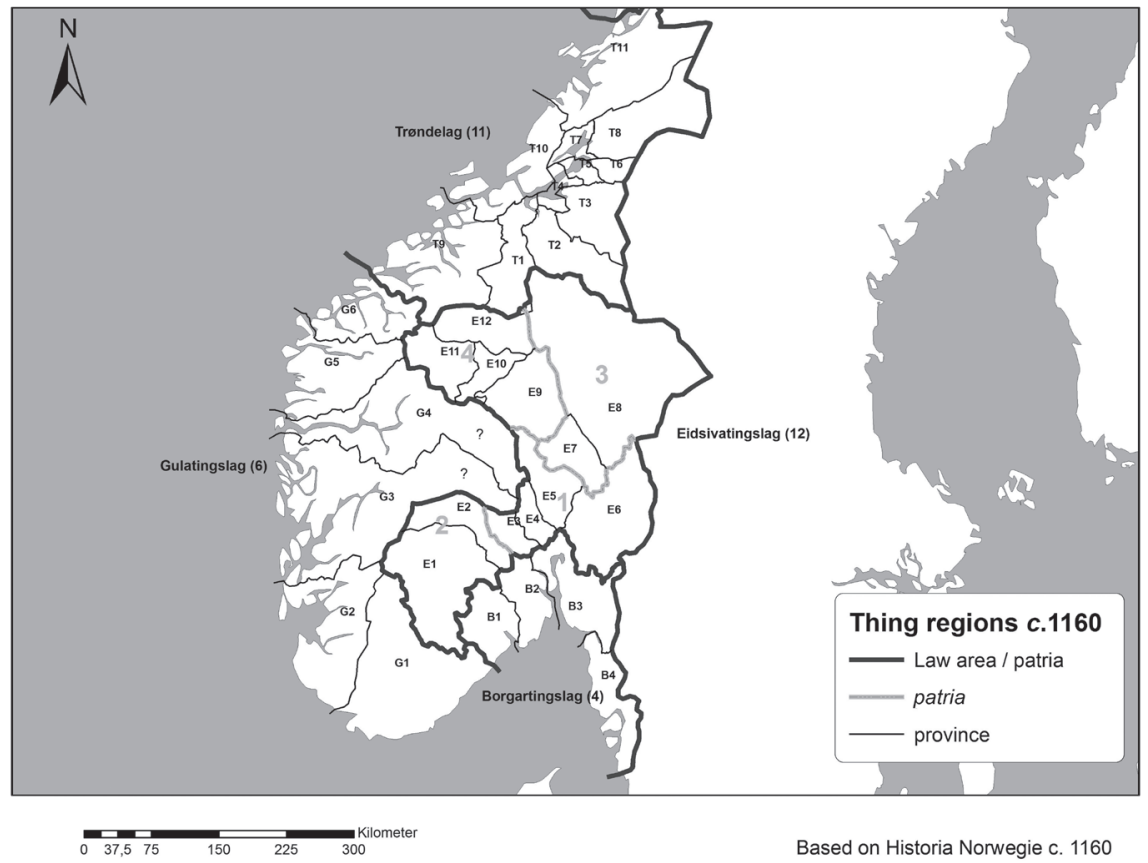

Figure 8.5 The author's reconstruction of the main law-areas (lagting) and law-provinces, according to Historia Norwegie, c.1150-75. See Storm, Monumenta Historia Norvegice, for another suggestion with slightly different identifications (Frode Iversen)

The works of Indrebø and Bull vary somewhat in precision, which necessitates a partly revised overview of the primary sources, supplemented by maps produced in conjunction with the publication of the Skattematrikkelen 1647 (the tax record of 1647). The Historia Norwegie of AD 1150-75 is another important source for assessing the administrative landscape of the country (Figure 8.5). ${ }^{35}$

The medieval administrative landscape has been reconstructed using geographic information systems (GIS), and this forms the basis of the present analysis of courtyard sites. GIS shapefiles have been produced for different units at four levels: the law area (patria), the province, the ship-district (skipreide), ${ }^{36}$ and, in the case of Hålogaland, subdivisions of these (fjerdinger and tinglag). Not all levels can be reconstructed in all areas with the same degree of certainty. The units have been digitised and, where they correspond, attached (using snapping) to the modern municipal borders (N 1000) or farm boundaries, based on so-called

Historia Norvegia. Latinske kildeskrifter til Norges historie i middelalderen utgivne efter offenlig foranstalting (Kristiania, Brøgger, 1880).

35 I. Ekrem and L. B. Mortensen (eds), Historia Norwegie, trans. P. Fisher (Copenhagen, Tusculanum Press, 2003).

${ }^{36}$ See further below, in Discussion. 
FKB-data (Felles KartdataBase) from Statens Kartverk. The coordinates of the courtyard sites were retrieved from the National Cultural Heritage Database (Askeladden).

The Historia Norwegie divides Norway into three main areas: the Coastal Land (Zona itaque maritime), the Middle or Mountain Area (Mediterranea zona/ De montains Norwegie) and Finnmark (De Finnis). The Coastal Land and the Mountain Area were subdivided into patriae and provinces, while this is not mentioned in the case of Finnmark, which was populated by Sámi. These subdivisions have been considered as reflecting two administrative levels, each with their own assemblies. ${ }^{37}$

The coastal landscape consisted of four patria: Viken in the east (Sinius orientalis), the Gulathing-area (Gulacia), Trondheim (Trondemia) and Hålogaland (Halogia). This division corresponds to the Borgarthing-area, the Gulathing-area, Trøndelag and Hålogaland, which constituted individual legal units. The identification of the provinces in the coastal areas in the south is unproblematic. ${ }^{38}$ However, where Hålogaland is concerned there are certain ambiguities, since the number of provinces is not specified for this law area. According to the manuscript, there were XXX (30) provinces in total along the coastal area and twenty-one are specified for the other law areas. ${ }^{39}$ This may assign nine possible provinces to Hålogaland. Munch, however, argued that the number XXX must have been wrong, and saw Hålogaland as one county and thus one province. ${ }^{40}$ Storm followed this lead and corrected the number to XXII, while remarking that the manuscript read XXX. ${ }^{41}$

Such a mistake in the original manuscript is unlikely. Hålogaland, having over $600 \mathrm{~km}$ of coastline, must have been divided into several provinces. Furthermore, nine provinces seem to correspond to the division of this area in the high and late Middle Ages ${ }^{42}$ and it may thus be assumed that the manuscript is valid: I have identified and suggested nine possible provinces in Tables 8.1 and 8.2.

In 1567 the minor units in Hålogaland were called fjerdinger (quarters) in the southern part and tingsted in the north. The earliest evidence for this organisation appears in the 1430s in Aslak Bolts' cadastre. ${ }^{43}$ The units are systematically

\footnotetext{
${ }^{37}$ I. Ekrem, Nytt lys over Historia Norwegie: mot en løsning $i$ debatten om dens alder (Bergen, Tuscalanum Press, 1998), at p. 32; Ekrem and Mortensen, Historia Norwegie, pp. 117, 178; K. Robberstad, 'Ordet patria i Historia Norvegiæ', Historisk Tidsskrift, 35 (1949-51), 187-91.

${ }^{38} \mathrm{Cf}$. Storm, Monumenta Historia Norvegice.

${ }^{39}$ Iversen, Hålogaland.

40 P. A. Munch, Symbolae ad historiam antiquiorem rerum Norvegicarum (Christiania, Werner, 1850), at p. 30

${ }^{41}$ Storm, Monumenta Historia Norvegice, p. 176.

$42 \mathrm{Cf}$. Indrebø, Fjordung.

43 J. G. Jørgensen (ed.), Aslak Bolts jordebok (Oslo, Riksarkivet, 1997), pp. 87-9, 97; Indrebø, Fjordung, p. 28; G. Storm, Norges gamle Love indtil 1387 IV (Christiania, Grøndahl \& Søn, 1885), p. 773.
} 
Table 8.1 The main law-areas (lagting) and law-provinces in Norway, c.1150-75

\begin{tabular}{|c|c|c|c|}
\hline MAIN AREA & $\begin{array}{l}\text { LAW AREA } \\
(\text { PATRIA })\end{array}$ & Province & IDENTIFICATION \\
\hline \multirow[t]{4}{*}{$\begin{array}{l}\text { Coastal land } \\
10 \text { towns (Decapolis) } \\
\text { Four patria } \\
22 \text { or } 30 \text { provinces }\end{array}$} & $\begin{array}{l}\text { Viken - from } \\
\text { the boundary } \\
\text { of Denmark to } \\
\text { Rygjabit }\end{array}$ & 4 & $\begin{array}{l}\text { Ranrike (B4) } \\
\text { Vingulsmark (B3) } \\
\text { Vestfold (B2) } \\
\text { Grenland (B1) }\end{array}$ \\
\hline & $\begin{array}{l}\text { The Gulating - } \\
\text { to the island of } \\
\text { Mien }\end{array}$ & $\begin{array}{l}6 \text { Møre is mentioned } \\
\text { as the most } \\
\text { remote county (= } \\
\text { northernmost) } \\
\text { Valdres and } \\
\text { Hallingdal are located } \\
\text { between the Coast } \\
\text { Land and Mountain } \\
\text { Land under the } \\
\text { Gulating }\end{array}$ & $\begin{array}{l} \\
\text { Agder (G1) } \\
\text { Rogaland (G2) } \\
\text { Hordaland (G3) } \\
\text { Sogn (G4) } \\
\text { Firda (G5) } \\
\text { Sunnmøre (G6) }\end{array}$ \\
\hline & Trøndelag & $\begin{array}{l}11 \text { ( } 8 \text { by the fjord and } \\
3 \text { outside the fjord) }\end{array}$ & $\begin{array}{l}\text { Orkdal (T1) } \\
\text { Gauldal (T2) } \\
\text { Stjørdal (T3) } \\
\text { Strinda (T4) } \\
\text { Skaun (T5) } \\
\text { Verdal (T6) } \\
\text { Innerøya (T7) } \\
\text { Sparbu (T8) } \\
\text {--------- } \\
\text { Romsdal (T9) } \\
\text { Nordmøre (T10) } \\
\text { Namdal (T11) }\end{array}$ \\
\hline & $\begin{array}{l}\text { Hålogaland, } \\
\text { north until } \\
\text { Vegestav, which } \\
\text { is separated by } \\
\text { Bjarmeland }\end{array}$ & $\begin{array}{l}\text { Not specified. } 22 \text { or } \\
30 \text { provinces in total, } \\
\text { and thus } 1 \text { or } 9 \text { in } \\
\text { Hålogaland }\end{array}$ & $\begin{array}{l}\text { If 9: } \\
\text { Herøy halvfylke } \\
\text { (Alstadhaug } \\
\text { syssel) } \\
\text { Rødøy halvfylke } \\
\text { Bodø syssel } \\
\text { Steigar syssel } \\
\text { Lofoten syssel } \\
\text { Ulvøy syssel } \\
\text { (Vesterålen) } \\
\text { Andenes syssel } \\
\text { Senja } \\
\text { Troms }\end{array}$ \\
\hline
\end{tabular}

(continued) 
Table 8.1 (continued)

\begin{tabular}{|c|c|c|c|}
\hline MAIN AREA & $\begin{array}{l}\text { LAW AREA } \\
(\text { PATRIA })\end{array}$ & Province & IDENTIFICATION \\
\hline \multirow[t]{4}{*}{$\begin{array}{l}\text { Mountain and middle } \\
\text { land. } \\
\text { Four patria, } 12 \\
\text { provinces, borders to } \\
\text { Götaland and reaches } \\
\text { north up to Trøndelag }\end{array}$} & Patria 1 & $\begin{array}{l}\text { 4? Romerike } \\
\text { and Ringerike } \\
\text { and unnamed } \\
\text { neighbouring } \\
\text { provinces (in plural) }\end{array}$ & $\begin{array}{l}\text { Romerike (E6) } \\
\text { Ringerike (E5) } \\
\text { Neighbouring } \\
\text { province } 1 \text { (E4) } \\
\text { Modum? } \\
\text { Neighbouring } \\
\text { province } 2 \text { (E3) } \\
\text { Sigdal? }\end{array}$ \\
\hline & Patria 2 & $\begin{array}{l}\text { 2. Telemark and an } \\
\text { unnamed and remote } \\
\text { area described as } \\
\text { remotes ruribus) }\end{array}$ & $\begin{array}{l}\text { Øvre Telemark } \\
\text { (E1) } \\
\text { Remote area (E2) } \\
\text { Numedal? }\end{array}$ \\
\hline & Patria 3 & $\begin{array}{l}\text { 2. Hedmark med } \\
\text { Alvdalen }\end{array}$ & $\begin{array}{l}\text { Hedmark (E7) } \\
\text { Østerdalen (E8) }\end{array}$ \\
\hline & Patria 4 & $\begin{array}{l}\text { 4? Gudbrandsdalen } \\
\text { and Lom, including } \\
\text { unspecified } \\
\text { neighbouring } \\
\text { provinces (in plural); } \\
\text { the boundary is } \\
\text { marked by the Dovre } \\
\text { Mountain }\end{array}$ & $\begin{array}{l}\text { Gudbrandsdalen } \\
\text { (E9) } \\
\text { Lom (E11) } \\
\text { Neighbouring } \\
\text { province 1 (E10) } \\
\text { Vågå? } \\
\text { Neighbouring } \\
\text { province 2 (E12) } \\
\text { Lesja? }\end{array}$ \\
\hline
\end{tabular}

recorded in official accounts for the years $1566-7 .{ }^{44}$ I have identified the existence of forty-four minor units in Hålogaland in 1567, while fifty-two are recorded in the Tax Cadastre of 1647. These represent the basis of my reconstruction of a total of thirteen ship-districts (skipreider), nine provinces and four larger areas (Figures 8.6 and 8.7). ${ }^{45}$ I perceive these to be units on different levels, but there is also a question of chronology, and whether the ship-districts were introduced later. Unfortunately, these latter are problematic to identify more precisely. According to King Magnus's will, there were thirteen ship-districts in Hålogaland in 1277, and the Gulathing Law states that seven ships came from the southern

\footnotetext{
${ }^{44}$ A. Steinnes (ed.), Norske lensrekneskapsbøker 1548-1567: 5 B: Rekneskap for Bergenhus len 1566-1567 Utgift. C, Dei nordlandske lena og Finnmark. D, Ekstrakt (Oslo, Dybwad, 1943), pp. $137-266$.

${ }^{45}$ Indrebø, Fjordung, pp. 68-9, 74-6.
} 


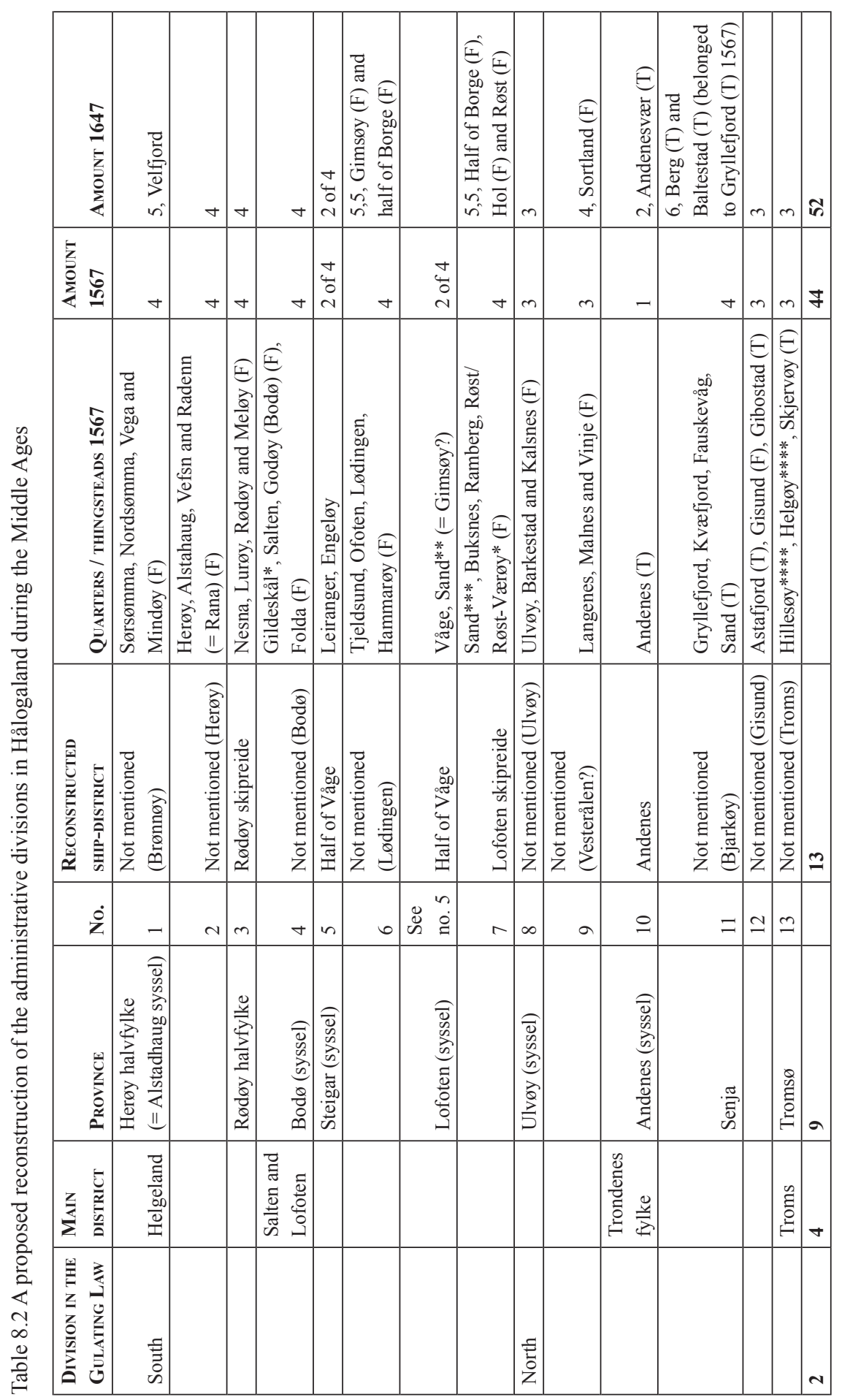




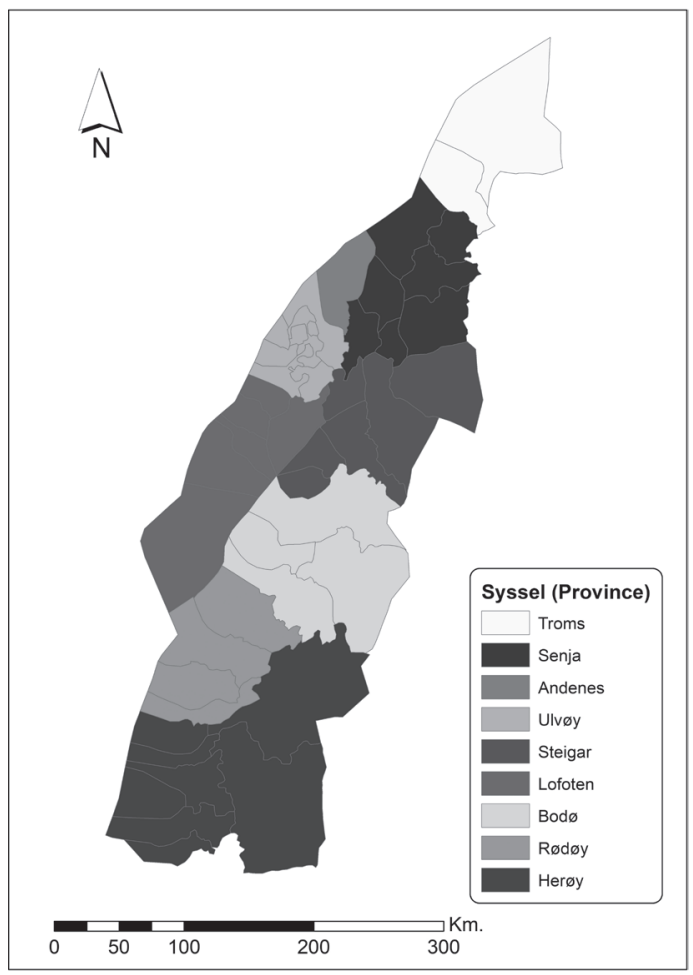

Figure 8.6 A proposed reconstruction of the administrative divisions in Hålogaland, 1150-75, suggesting nine provinces (Frode Iversen)

part and six from the north. ${ }^{46}$ Most probably, the border between the north and the south was either drawn between Lofoten and Vesterålen or between Andenes and Vesterålen. ${ }^{47}$ Charters name only three ship-districts, all in the 1400s; Loofota skipredhu (1425), Vagha skiparedhoe (1472) and Raudøyar skipreide (1497). ${ }^{48}$ Judging by the term fjerding (quarter), there should, at least ideally, have been four of these in each ship-district. A tentative reconstruction of the thirteen ship-districts must be based on this simple fact.

The historian Rolf Fladby argued for a link between clerical districts and skipreider. ${ }^{49}$ A clerical district (Norw. prestegjeld) is an area divided into several parishes. There were thirteen such districts during the late Middle Ages in

${ }^{46}$ C. C. A. Lange et al. (eds), Diplomatarium Norvegicum. Oldbreve til Kundskab om Norges indre og ydre Forhold, Sprog, Slagter, Sceder, Lovgivning og Rettergang i Middelalderen, vols 1-23 (Christiania/Oslo, P. T. Mallings Forlagshandel/Norsk Historisk Kjeldeskrift-institutt, 1849-2011), no. 3; The Gulathing law $\S 315$ reads ... vij. $i$ syðri holfo. En. vi i nørðre holfo.

47 Iversen, 'Hålogaland'.

48 Diplomatarium Norvegicum II no. 684; V no. 477; V no. 879.

49 R. Fladby, Hvordan Nord-Norge ble styrt. Nordnorsk administrasjonshistorie fra 1530-åra til 1660 (Tromsø, Universitetet i Tromsø, 1978). 

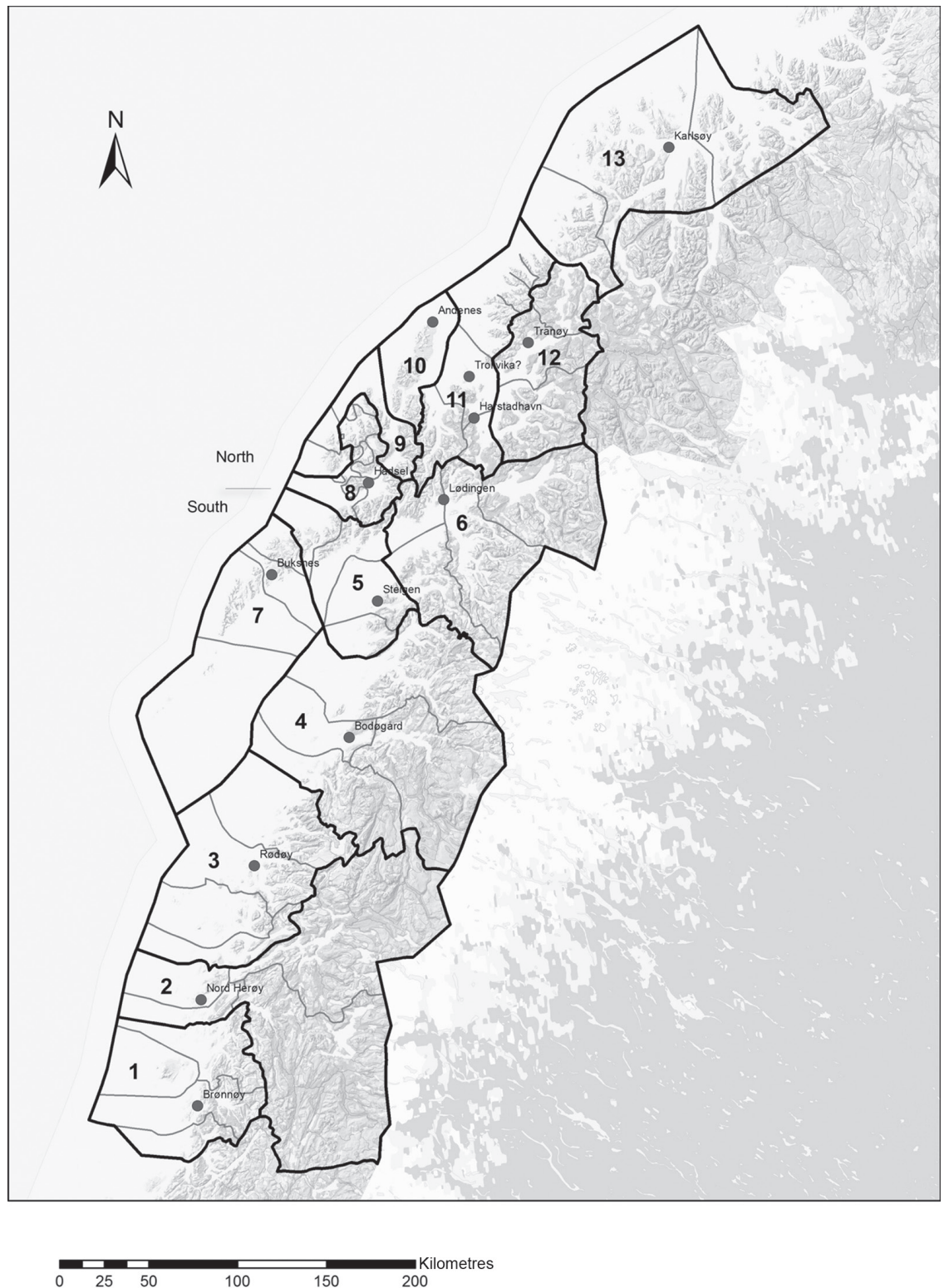

Figure 8.7 A proposed reconstruction of the administrative divisions in Hålogaland, mid-10th century onwards suggesting thirteen ship-districts (skipreider) and forty-four local thing areas. The grey dots are naval centres (boathouses) recorded in 1609, according to H. D. Bratrein, 'Skjøttebåter og leidangsskip i Nord-Norge' (Frode Iversen) 
Hålogaland. ${ }^{50}$ However, Håvard D. Bratrein rejected this notion and argued that the clerical districts were of a later date. ${ }^{51}$ Instead, he presented a reconstruction based on Hartvig Billes's records of 1609, which list thirteen so-called communal naval encampments and boathouses (skjøttebåtstasjoner) in Hålogaland. These may have been the centres of the ship-districts, and linked to the leidang system (the organisation of the military fleet) in the Middle Ages. Bratrein found evidence of such encampments at Brønnøysund, by Fogdegården at Herøy, Rødøy, Bodø (Gildeskål parish), Steigen, Lødingen (by Tjeldsund), Buksnes (by the church), Ulvøy (by Hadsel church), Andenes vær, Harstadhavn, Trollvik at Sand parish (unidentified), Tranøy (by the church) and at Karlsøy vær. ${ }^{52}$ He then reconstructed the ship-districts around these naval centres. However, there are too few quarters mentioned in 1567 to support the theory of four quarters to each ship-district, especially in the northern part of Hålogaland. Neither is there consistency between yet another source from 1557 and the list from $1609 .{ }^{53}$ In my view, Bratein's proposal is nonetheless the most plausible to date.

My method for reconstructing ship-districts is slightly different (Figure 8.7). I have taken the naval centres into consideration but, unlike Bull, I perceive Våge and Lofoten as separate ship-districts and not a single unit. ${ }^{54}$ Although slightly less reliable, the saga literature informs us that Sigurd Ranesson (c.1070-1130), from the farm of Steigen in Engeløy quarter, was able to lay his case before the thing-meeting held at Kjefsøy, identified as belonging to the Våge quarter. ${ }^{55}$ In my view, this indicates that the quarters of Engeløy and Våge, one on each side of the fjord, had a common assembly, and that they most likely belonged to the same ship-district (Våge) (Figure 8.7 and Table 8.2).

\section{Results}

We will now take a closer look at the courtyard sites at Bjarkøy and Åse, which are among the most extensive and well-documented sites of their kind in Hålogaland. They may, as we shall see, have succeeded each other chronologically. I will also review the sites at Leknes and Steigen, which are among the grandest, and most likely from different time periods.

\footnotetext{
${ }^{50}$ Brønnøy, Alstahaug, Rødøy, Gildeskål, Salten, Steigen, Lødingen, Værøy, Lofoten, Vesterålen, Andenes, Trondenes and Tromsø.

${ }^{51}$ H. D. Bratrein, 'Skjøttebåter og leidangsskip i Nord-Norge', Acta Borelia. A Norwegian Journal of Circumpolar Societies, 1 (1984), 27-37.

52 Danske kanselli, Norske innlegg, erklæring fra Hartvig Bille 22/7-1609. Riksarkivet.

${ }^{53} \mathrm{H}$. Winge (ed.), Lover og forordningar 1536-1605. Norsk lovstoff $i$ sammendrag (Oslo, Norsk lokalhistorisk institutt, 1988), no. 360; Lundh and Sars, Norske Rigs-Registranter II, pp. 252-3. ${ }^{54}$ The Trollvik site is not possible to identify for certain (Bratrein, Skjøttebåter, note 17). There is one site missing in Vesterålen, ship-district 9 (Figure 8.7).

${ }_{55}$ G. Storm, Sigurd Ranessøns process. Pingasaga milli Sigurðar konungs ok Eysteins konungs (Kristiania, Malling, 1877), pp. 8, 49.
} 


\section{Bjarkøy and Åse}

The site Bjarkøy consisted of two rows with eight houseplots arranged around a central open courtyard with entrances to the east and west. The site is situated on a high ridge in uncultivated terrain surrounded by bogland. It is located approximately $1 \mathrm{~km}$ from the farmsteads of Øvergård, Nergård and Austnes, and about $400 \mathrm{~m}$ from the seashore at Einebærvika in the south where there is also a prehistoric burial site. The external measurements of the courtyard site are $55 \mathrm{~m}$ (east-west) $\times 22 \mathrm{~m}$ (north-south), and the circumference is around $170 \mathrm{~m}$. The central open courtyard measured $34 \times 25 \mathrm{~m}$, and the entrance to the east was $5 \mathrm{~m}$ wide. There were remains of a low central mound of about $5 \mathrm{~m}$ diameter. The north-western part of the site had been subjected to disturbance prior to the excavations by Lund, and it is uncertain whether the site originally contained traces of sixteen houseplots, as Lund suggests (Figure 8.8). Lund investigated all the houseplots in the southern row and three in the northern row, all in all eleven houseplots. The cultural layers were $20-40 \mathrm{~cm}$ thick. Concentrations of fire-cracked stones, charcoal and ash were found along the mid-axis in the houseplots and interpreted as hearths. Lund found traces of postholes and hearths in several stratigraphic levels. The traces overlap and indicate two or three phases of activity. ${ }^{56}$

Thirty-two small circular mounds (fire-mounds or heaps of fire-cracked stones) were found immediately outside the courtyard site. They measured $3-7 \mathrm{~m}$ in diameter and were around $75 \mathrm{~cm}$ in height. Lund investigated eight of them, and found pits of charcoal dug into the upper part of the mounds $(c .1 .4 \mathrm{~m}$ diameter in width and $35 \mathrm{~cm}$ deep). These have been interpreted as cooking pits. ${ }^{57} \mathrm{In}$ addition, thirtyeight finds recovered from the courtyard site include a Viking Age glass bead, slate whetstones, late Iron Age arrowheads and knives. Pottery and a quartzite whetstone were also found, most likely dating from the Migration Period. A total of ten radiocarbon dates were taken from seven of the houseplots and three of the mounds. Storli suggests a main phase of activity from AD 500 to $900 .^{58}$

The exterior measurements of the unit at Åse are $40 \mathrm{~m} \times 43 / 44 \mathrm{~m} .{ }^{59}$ It has a circular shape, with an entrance located in the east. It is situated $3.5 \mathrm{~km}$ from the historical settlement of Åse, on a sandbank by the bogland at Finnklokneset. Visually, it is well hidden in the landscape. The site is $3.5 \mathrm{~m}$ above sea level and $450 \mathrm{~m}$ from the nearest shoreline. The cultural layers were up to $40 \mathrm{~cm}$ in depth and about forty-three radiocarbon samples were taken from a total of fourteen houseplots. The top, middle and bottom layers of twelve of the houseplots were sampled and dated by Storli. Sjøvold initially excavated two houseplots in 1948 and 1949, and

\footnotetext{
${ }^{56}$ Johansen and Søbstad, 'De nordnorske tunanleggene', 14-22; Storli, Hålogaland før rikssamlingen, pp. 48-51.

57 Johansen and Søbstad, 'De nordnorske tunanleggene', 22.

58 Storli, Hålogaland før rikssamlingen, p. 50.

59 Johansen and Søbstad, 'De nordnorske tunanleggene', 43-4; Sjøvold, Ase-anlegget; Storli, Hålogaland før rikssamlingen, pp. 52-5.
} 


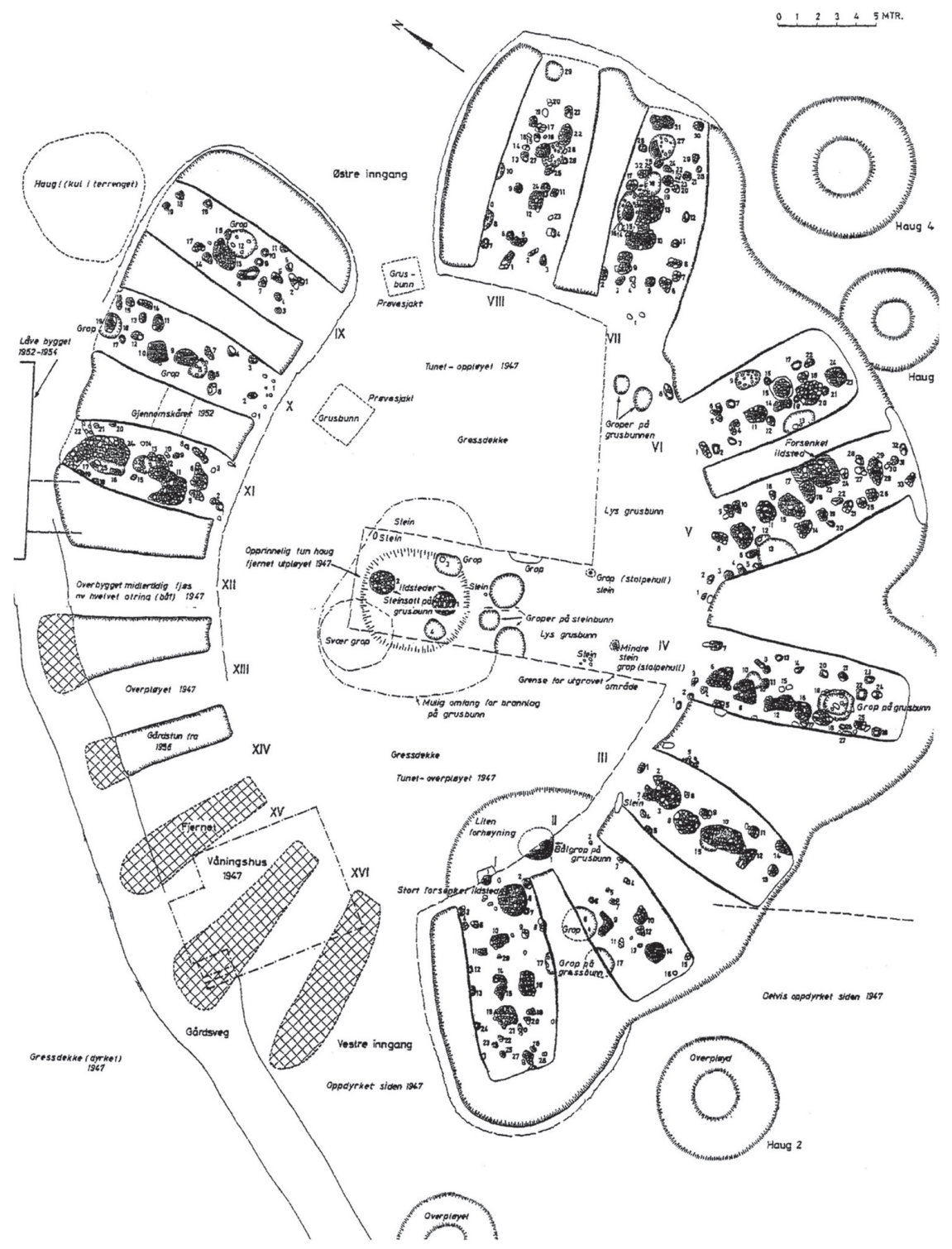

Figure 8.8 Drawing of the courtyard site at Bjarkøy by H. E. Lund (after Johansen and Søbstad, 'De nordnorske tunanleggene')

provided samples from houses 2 and 13 that were radiocarbon dated in $1968 .{ }^{60}$ The floors of these houses measured $8 \times 2.5 \mathrm{~m}$ (house 2 ) and $10 \times 4 \mathrm{~m}$ (house 13). During the excavations, Sjøvold found traces of two hearths in each of the houseplots. The houseplots that provided the latest dates from the lowest layers (houses

${ }^{60}$ Sjøvold, 'Åse-anlegget', 25. 
1 and 14) are located between the houseplots investigated by Sjøvold (2 and 13). Presumably, the northern part of the unit had undergone some restructuring at one point. However, only a few objects have been found; a possible fibula in houseplot 13 , a knife in houseplot 2 , rivets heads and some unidentified iron objects.

In conclusion, the courtyard site at Åse was constructed AD $120 \times 340$. It was later subjected to improvements and expansion of the northern and north-eastern parts, where the houseplots have a later date. The ground plan is representative of the time around $\mathrm{AD} 400$ and was not changed until it fell out of use in about AD $540 / 550$. I agree with Storli that the courtyard site at Åse was most likely abandoned prior to $\mathrm{AD} 600 .{ }^{61}$

\section{Leknes and Steigen (Vollmoen)}

In Lofoten and in Salten there are two large courtyard sites: Leknes at Vestvågøy and Steigen at Engeløy. Leknes is surrounded by substantial boglands and is located in the bay of the Buknesfjord about $170 \mathrm{~m}$ north of Haldsvågen. Originally, it was mistakenly interpreted as a burial site, containing fifteen or sixteen oblong grave mounds arranged in a circle, of which two were excavated in $1885 .^{62}$ The site had been subjected to severe damage when Lund reinterpreted it as a courtyard site in 1950 . Only four houseplots were preserved, leaving the site with internal measurements of $9 \times 3.5 \mathrm{~m} .{ }^{63}$ Surrounding the unit were several so-called fire-mounds, Lund demarcating eight in his sketch from 1951. He thought that the Leknes site had originally contained fourteen houseplots, with an external circumference of $60 \times 45-50 \mathrm{~m}$ and an internal courtyard of $25 \times 30 \mathrm{~m}$. Hearths in very low stratigraphic levels of house 2 , and considerable layers of charcoal recorded underneath the 'oblong grave-mounds' in 1885 suggest multiple phases of use. ${ }^{64}$ Fragments of bucket-shaped pottery and a whetstone of quartzite in houseplot 3 indicate early Iron Age activity and radiocarbon dating confirms this (AD 120-390, 1-sigma). The unit at Leknes was most likely in use during the early Iron Age, probably between $\mathrm{AD} 200$ and 600.

The site at Steigen, Vollmoen, was initially discovered in 1926 and investigated by Lund in 1941 and 1942. It is located far north at the farmstead called Nedre Steigen in Engeløy quarter, and hidden between Vesthornet and Steigbergtinden, $800 \mathrm{~m}$ from the beach to the south. By the steep foot of Steigberget, immediately north of an area of cultivated land, four prehistoric boat-houses

\footnotetext{
${ }^{61}$ Storli, Hålogaland før rikssamlingen, p. 53.

62 Johansen and Søbstad, 'De nordnorske tunanleggene', p. 11; O. Nicolaissen, 'Undersøgelser i Nordlands Amt 1884', Foreningen til norske fortidsmindesmerkers bevaring, Aarsberetning for 1884 (1885), 1-23, at 16; O. Nicolaissen, 'Undersøgelser i Nordlands Amt 1890', Foreningen til norske fortidsmindesmerkers bevaring, Aarsberetning for 1890 (1891), 1-8, at 5; Storli, Hålogaland før rikssamlingen, p. 59.

${ }^{63}$ Number ID 47535 in the Norwegian Cultural Heritage Askeladden database: http://askeladden. ra.no/.

${ }^{64}$ Johansen and Søbstad, 'De nordnorske tunanleggene', 41.
} 


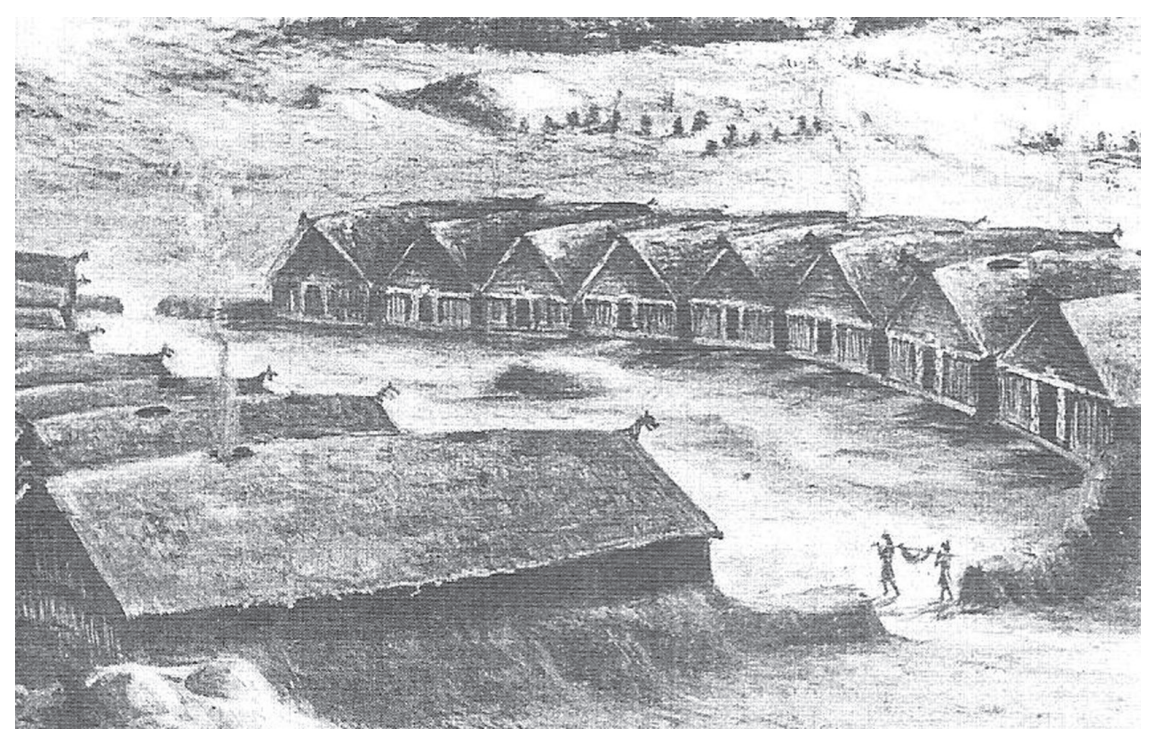

Figure 8.9 Reconstruction of Steigen by A. Reinert (printed in Lund, 'Håløygske høvdingeseter')

have been discovered. ${ }^{65}$ Lund thought that these had a connection to the courtyard site, which comprised sixteen houseplots, arranged into two confronting rows of eight (Figure 8.9). Houseplot 1, in the north, is somewhat isolated, disturbing the otherwise symmetrical layout, while the row to the west is slightly more curved than the eastern row. The external measurements of the complete unit are $69 \times 55 \mathrm{~m}$, and the internal courtyard measures $60 \times 30 \mathrm{~m}$. According to Lund, a low central mound had been located in the middle of the courtyard. The houseplots have entrances facing the central courtyard. The turf walls are up to $50 \mathrm{~cm}$ in height. The houseplots vary in size, from 9 to $13 \mathrm{~m}$ in length and 3 to $4 \mathrm{~m}$ in width. $50 \mathrm{~cm}$ deep cultural layers and several hearths along the mid-axis of the houses have been recorded in all the houseplots. Hearths located in different stratigraphic levels indicate multiple phases of activity. However, in houseplots 10 and 15 the hearths were not aligned along the mid-axis, which could indicate a restructuring of these buildings. Animal teeth and bones from both large (cow) and small (sheep) animals were found in all of the houseplots (species determined by bones in houses 1-3, 5-7 and 9). Surrounding the unit were twenty-six fire-heaps and forty presumed cooking-pits. Lund examined seventeen of the fire-heaps and several of the cooking pits. Large amounts of animal bone and teeth were found in three of the fire-heaps (3,6 and 15) and in the courtyard itself. In fire-heap 3, by houseplot 1, bone fragments of horse were found. In several of the fire-heaps, alternate layers of sand and charcoal were observed.

${ }^{65}$ Askeladden ID 37753. 
Similar stratigraphy is documented in houseplot $15 .^{66}$ This could indicate times of disuse between phases of activity, if the alternate layers were caused by wind and drift of sand.

Around fifty objects were recovered from the site, including a ferrule of bronze belonging to a scabbard, which was ornamented in the Jellinge style (R 516) (houseplot 12) and art-historically dated to AD 850-950. Lund also recovered beads in four or five houseplots $(9,10,11,13)$, a fire steel (houseplot 3 ), in addition to five iron knife blades, or fragments of such (houseplots 1, 2, 6 and 7). Fragments of soapstone vessels, a bronze spiral, an iron needle, a small piece of hack silver, an iron ring and a fragment of a quartzite whetstone were also recovered. The finds suggest a Viking Age date, ${ }^{67}$ supported by radiocarbon determinations from three houseplots in the western row $\left(9,12\right.$ and 15) and mound $26 .{ }^{68}$ The two samples provided the earliest dates of $\mathrm{AD} 470 \times 690$ (houseplot 12) and $\mathrm{AD}$ $540 \times 660$ (1-sigma). The latest radiocarbon date of $\mathrm{AD} 780 \times 1030$ is derived from houseplot 15, where fragments of soapstone vessels also suggest a Viking Age date. There is no record of at which stratigraphic levels the various samples in this courtyard site were taken, but a date range of $\mathrm{AD} 600-900 / 950$ for the whole unit seems reasonable. The absence of early Iron Age pottery also suggests that the unit is of a later date.

We shall now have a closer look at the possible connection between the courtyard sites and the administrative division of the northern part of Hålogaland during the Middle Ages.

\section{Discussion: The Courtyard Sites and the Administrative Landscape}

A central hypothesis in this work is that the establishment of petty-kingdoms resulted in the development of monopolies of violence within certain areas, where jurisdictions tied to warfare came under direct royal control. The courtyard sites can be interpreted as forerunners of this development, at a time where military jurisdiction was still in the hands of 'communal elites'. One indication of such a development is the so-called weapon-thing, which is mentioned in the law of Gulathing and the rural law of King Magnus Håkonsson ('the lawmender') 1274. ${ }^{69}$ This was an annual assembly held in the spring where the king's representatives inspected the weapons of the thing-men. Furthermore, it was forbidden

\footnotetext{
${ }^{66}$ I.e. photograph printed in Johansen and Søbstad, 'De nordnorske tunanleggene', 30.

${ }^{67}$ Number Ts 4539 a-b in the Tromsø Museum collection.

${ }^{68}$ Storli, Hålogaland før rikssamlingen, p. 65.

${ }^{69}$ B. Eithun, M. Rindal and T. Ulset (eds), Den eldre Gulatingslova. Norrøne tekster 6 (Oslo, Riksarkivet, 1994), at § 309; G. Storm and E. Hertzberg (eds), Den nyere Lands-Lov, utgiven av Kong Magnus Haakonsson. G.), in Norges gamle Love indtil 1387: 2: Lovgivningen under Kong Magnus Haakonssøns Regjeringstid fra 1263 til 1280, tilligemed et Supplement til første Bind (Christiania, Chr. Grøndahl, 1848), pp. 1-178, at § III, 12.
} 
to carry weapons at the law-things ${ }^{70}$ where previously this may have been more common. This is suggested by the term vappentak, mentioned both in the provincial laws and the law of Magnus. ${ }^{71}$ It denotes the joint decision and adherence by the thing-men, of lifting and touching weapons when in agreement. ${ }^{72}$ Tacitus claimed, in $\mathrm{AD}$ 98, that the men of the thing (concilium) in Germanic areas were armed during meetings. When the participants found it just, he writes, they took their seats armed. ${ }^{73}$ Most likely, this reflects an older tradition, while the weapons ban must be younger. In 1189, a prohibition against bearing arms at things and in churches emerged in Norway. ${ }^{74}$

Hypothetically, this could indicate that petty-kings during the late Iron Age seized control of a communal military practice and enforced special weapon-things, while also enforcing a ban on weapons at the law-things. The weapon-things were held within the skipreider, which were closely connected to the organisation of the military fleet, the so-called leidang, in the mid-10th century. ${ }^{75}$ Could the courtyard sites in the north of Norway have lost their function due to such changes in the legal and administrative landscape? Furthermore, can this be connected to a differentiation between, on the one hand, specialised weapon-things, and, on the other, law-things, which held no military jurisdiction? According to the model above (Figure 8.3), a substantial change in the thing-system followed the establishment of supra-regional Christian kingdoms. During the 11th and 12th centuries, so-called Christian laws were developed. The new administrative ecclesiastical geography was largely structured in accordance with the previous law-areas. In Norway, the early dioceses established during the 11th century coincided with one or two law areas each, and the circuits of the so-called fylkes-churches (ON fylkiskirkja, 'county church') followed a subdivision of these. In time, this led to a further division of religious and secular law and administrative systems. After the Reformation (1536/7), and with the development of a particularly strong royal power in the reign of King Christian IV (1588-1648), major legal reforms took place. This changed the thing-system

70 Storm and Hertzberg, Den nyere Lands-Lov, § I, 5.

${ }^{71}$ Eithun et al., Den eldre Gulatingslova, § 279; Storm and Hertzberg, Den nyere Lands-Lov, § VII, $56,2$.

72 J. Fritzner, Ordbog over Det gamle norske Sprog, 4th edn (Oslo, Universitetsforlaget, 1973 (1867)), p. 864; K. Robberstad, 'Merknader', in K. Robberstad (ed. and trans.), Gulatingsloven, Norrøne bokverk, 33 (Oslo, Det norske samlaget, 1952), pp. 304-63, at 354.

${ }^{73}$ Ut turbae placuit, considunt armati, C. Tacitus, Agricola; Germania: Lateinisch und deutsch, ed. and trans. A Städele, Sammlung Tusculum (Darmstadt, Wissenschaftliche Buchgesellschaft, 1991), Germania ch. 11.

${ }^{74}$ P. A. Munch and R. Keyser (eds), Norges gamle Love indtil 1387, vol. 1: Norges Love celdre end Kong Magnus Haakonssøns Regjerings-Tiltrcedelse i 1263 (Christiania, R. Keyser and P. A. Munch, 1846), p. 409; G. Storm (ed.), Regesta Norvegica: kronologisk Fortegnelse over Dokumenter vedkommende Norge, Nordmaend og den norske Kirkeprovins: 1: 822-1263 (Christiania, Riksarkivet, 1898), p. 86 , no. 198 .

${ }^{75}$ G. A. Ersland and T. H. Holm, Krigsmakt og kongemakt 900-1814, Norsk forsvarshistorie, 1 (Bergen, Eide forlag, 2000). 
dramatically by the introduction of a magistrate - a sworn writer (Sorenskriver) on local things - in 1591, which considerably increased the king's influence on legal practice at the lowest level. ${ }^{76}$

Several archaeologists and historians have discussed the extent of the Norse and Sámi population in Viking Age Hålogaland based on, for example, the distribution of place-names, graves and so-called farm mounds (Figure 8.10). ${ }^{77} \mathrm{In}$ general, the inner fjord areas seem to have been dominated by the Sámi population, while the coastal lands and the islands were inhabited by the Norse north to Karlsøy. ${ }^{78}$ Norse settlement in the area of Troms was probably not very extensive, as is demonstrated by the record of a mere 450 Iron Age graves in Hålogaland. ${ }^{79}$ In about 60 per cent (271 out of 450 ) of these, grave-goods include weapons. These are particularly interesting, since weapons are associated with men of full rights, and thus the thing-men. The northernmost weapon-grave prior to $\mathrm{AD} 600$ is from Stangnes at Tranøy in Senja and dates to the 5th century. ${ }^{80}$ None of the forty-four early Iron Age weapon graves is located in Troms (out of a total of 134 graves dated to this period). However, Late Iron Age weapon graves and graves containing prestigious grave-goods are known as far north as Karlsøy in Troms, with certain examples all the way up in Nordkapp and as far east as Ekkerøy in today's county of Finnmark. Large gravemounds of Iron Age date do not occur further north than Bjarkøy in the district of Senja. ${ }^{81}$

Early Iron Age courtyard sites in Hålogaland are dispersed along the coast, from Åse in the north to Øysund in the south, that is, from Andenes to Salten. The late Iron Age courtyard sites cover a wider geographical area, from Bjarkøy in the north to Botnmoen at Brønnøy in the south, that is, from Senja in the north to Helgeland in the south. There are no known courtyard sites in medieval Troms. It is possible that this distribution mirrors an extension of an earlier legislative area.

\footnotetext{
${ }^{76}$ O. G. Lundh and I. E. Sars (eds), Norske Rigs-Registranter-tildeels $i$ Uddrag Christiania: $3:$ 1588-1602 (Christiania, O. G. Lundh and I. E. Sars, 1865), p. 201.

77 O. Andersen, ‘Ofuohtagat - Samer og nordmenn i Ofoten' (unpublished master's thesis, University of Bergen, 1992); R. Bertelsen, Fra den eldste tida til ca. 1500 e. Kr., Lofotens og Vesterålens historie 1 (Stokmarknes, Municipalities in Lofoten and Vesterålen, 1985); Bratrein, Skjøttebåter; Bratrein, Karlsøy og Helgøy; H. Guttormsen, Ressurser og bosetning i Andenes len og Sortland fjerding fra ca 1000-1660 e. Kr. (Tromsø, Universitetet i Tromsø, 1983); L. I. Hansen, Handel i nord. Samiske samfunnsendringer ca. 1550-ca. 1700 (Tromsø, Universitetet i Tromsø, 1990); A. R. Nielssen, Fra Steinalderen til 1700-tallet-Lødingen, Tjeldsund og Tysfjords historie 4 (Lødingen, Kulturkontoret, 1990); A. Schanche, 'Jernalderens bosettingsmønster i et fleretnisk perspektiv', Framskritt for fortida i nord i Povl Simonsens fotefar, Tromsø museums skrifter, 22 (1990), 171-84; R. Stensland, Bosetninga i Steigen 1300-1660 (Tromsø, Universitetet i Tromsø, 1979).

${ }^{78}$ See map (Figure 10), Norges offentlige utredninger (NOU), no. 14, Ch. 9.2. (Justis- og politidepartementet 3, 2007).

79 T. Sjøvold, The Iron Age Settlement of Arctic Norway I-II, Tromsø Museums Skrifter 10, 1-2 (Tromsø, Tromsø Museum, 1962 and 1974); Storli, Hålogaland før rikssamlingen, p. 88.

${ }^{80}$ Storli, Hålogaland før rikssamlingen, appendix 2.

81 Storli, Hålogaland før rikssamlingen, p. 79.
} 


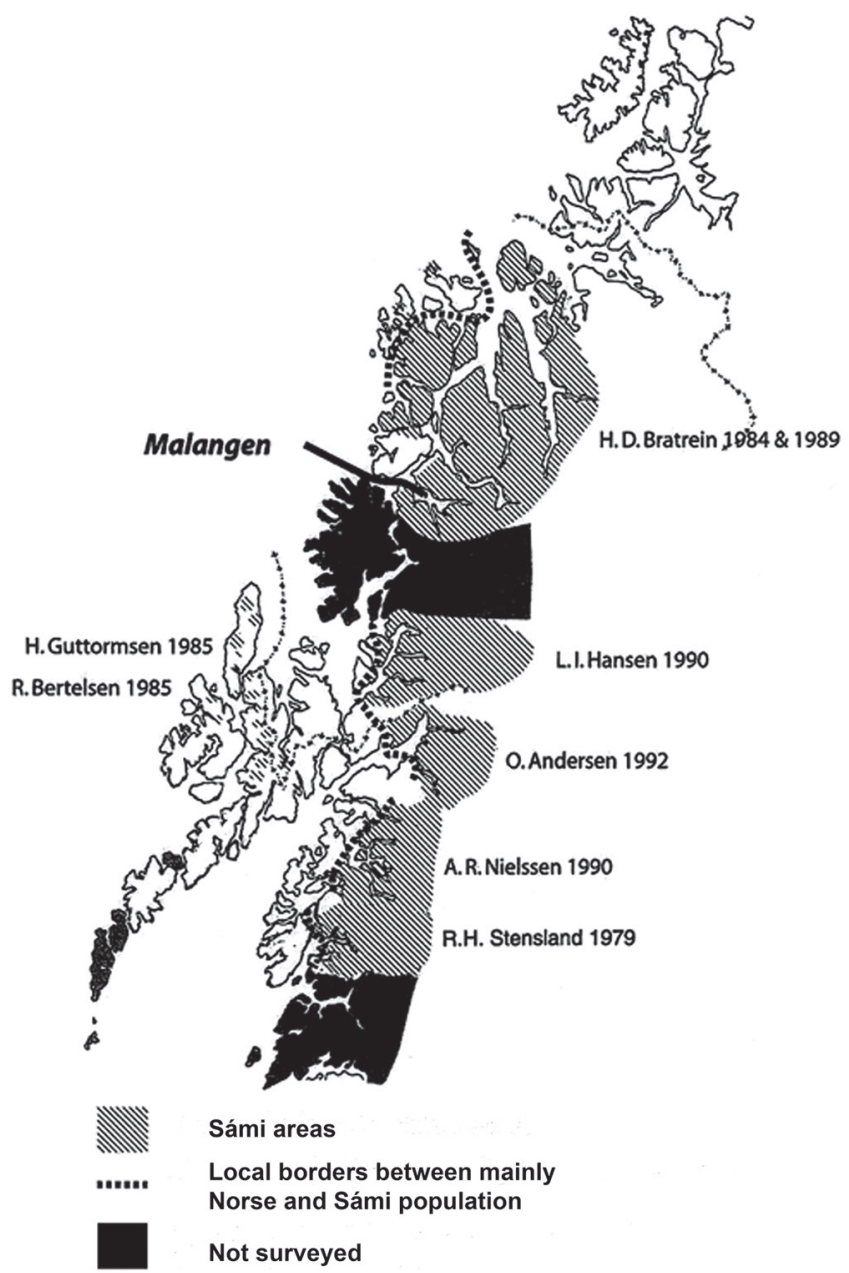

Figure 8.10 The suggested extent of the Norse and Sámi population in the Viking Age, northern part of Hålogaland. After Norges offentlige utredninger (NOU) no. 14, Ch. 9.2 (Justis- og politidepartementet 3,2007 )

Leknes and Åse are the largest early Iron Age units in Hålogaland, in addition to Tjøtta further south.

The site of Åse is located centrally for travellers from the outskirts of the area of Vesterålen, Andenes and Senja. It is approximately $100 \mathrm{~km}$ by sea-lane from both Korsodden in the south and Tennvold in the east, and $110-120 \mathrm{~km}$ from Malangenfjord in the north. Fourteen minor thing-units were recorded in this area in 1567. This corresponds to the number of houseplots on the Ase site. Archaeological evidence shows that the unit was in use until AD 500. A possible hypothesis is that the legislative area was extended further north during the late Iron Age, and 
formally included the area of Troms when the unit Bjarkøy was established. The courtyard site at Bjarkøy contains more houseplots than Åse, sixteen as opposed to fourteen, making Bjarkøy more substantial. The circumference of the ground plan here is also larger, measuring 1600 against 1000 square metres. Most likely, there were three minor thing-areas in Troms in AD 1567, Hillesøy, Helgøy and Skjervøy. However, the Norse settlement of Skjervøy was not established until AD $1500 .^{82}$ Thus only sixteen minor administrative units existed in this area during the Middle Ages, from Ulvøy in Vesterålen in the south to Helgøy in Troms in the north, which corresponds well with the number of houseplots at the courtyard site of Bjarkøy (Figure 8.11). ${ }^{83}$

My theory is that the individual thing-communities had their own houses within the courtyard site. Bjarkøy acquired the functions of Åse when the law area expanded further north. More specifically, this means that each of the following administrative areas of Ulvøy, Barkestad, Kalsnes, Langenes, Malnes, Vinje, Andenes, Gryllefjord, Kvæfjord, Fauskevåg, Sand, Astafjord, Gisund and Gibostad, were represented by their own houseplot at the site at Åse. When larger areas of Troms became part of the same jurisdiction, the legislative functions were moved from Åse and established at Bjarkøy, where the areas of Hillesøy and Helgøy were represented by their own houseplots. Hence, the additional two plots at Bjarkøy are evidence of a legislative restructuring. The site at Bjarkøy is located about $30 \mathrm{~km}$ farther east than Åse and thus more centrally in the expanded area. The distance from Karlsøy in the north to Bjarkøy is $200 \mathrm{~km}$, while the distance from the southernmost parts of the area was elongated by an additional $30 \mathrm{~km}$.

How many individuals were gathered from these areas? The houseplots at Bjarkøy have internal measures of 23 to 50 square metres (without deducting for curved walls). On average the houses are 36 square metres and vary up to 14 per cent in average width $(3.85 \mathrm{~m})$ and 20 per cent in average length $(9.4 \mathrm{~m})$. The buildings in the unit would have been quite similar in width $(3.3-4.4 \mathrm{~m})$, but varied in length $(7.5-11.3 \mathrm{~m})$. The larger buildings were located in the east (houseplots 7 and 8 ) and had double the internal space compared to the smallest buildings. How many individuals did these buildings hold? Let us briefly look to a historical analogy: during the larger regional legal assemblies held in Ryfylke in Rogaland in the 1600s, four, six or twelve men in addition to a sheriff from each local thing-area met, according to the thing-books. For example, at the Hesby thing, held 14 May 1616, 109 lagrettemenn and seventeen sheriffs met, which amounted to a delegation consisting of six men and a sheriff from each of the eighteen thing-areas in Ryfylke. ${ }^{84}$ The size of the delegation varied, according to the nature of the legal cases in question. At Bjarkøy, delegations of four or five individuals for each area would give 64-80 individuals, and six or seven would

${ }^{82}$ M. Fugelsøy, Skjervøy. Et prestegjeld og et herred i Nord-Troms (Skjervøy, Skjervøy kommune, 1970), p. 55; Bratrein, Karlsøy og Helgøy.

${ }^{83}$ See also Iversen, 'Community and Society', where this has been discussed in a somewhat different context.

${ }^{84}$ Iversen, 'Houses of Commons'. 


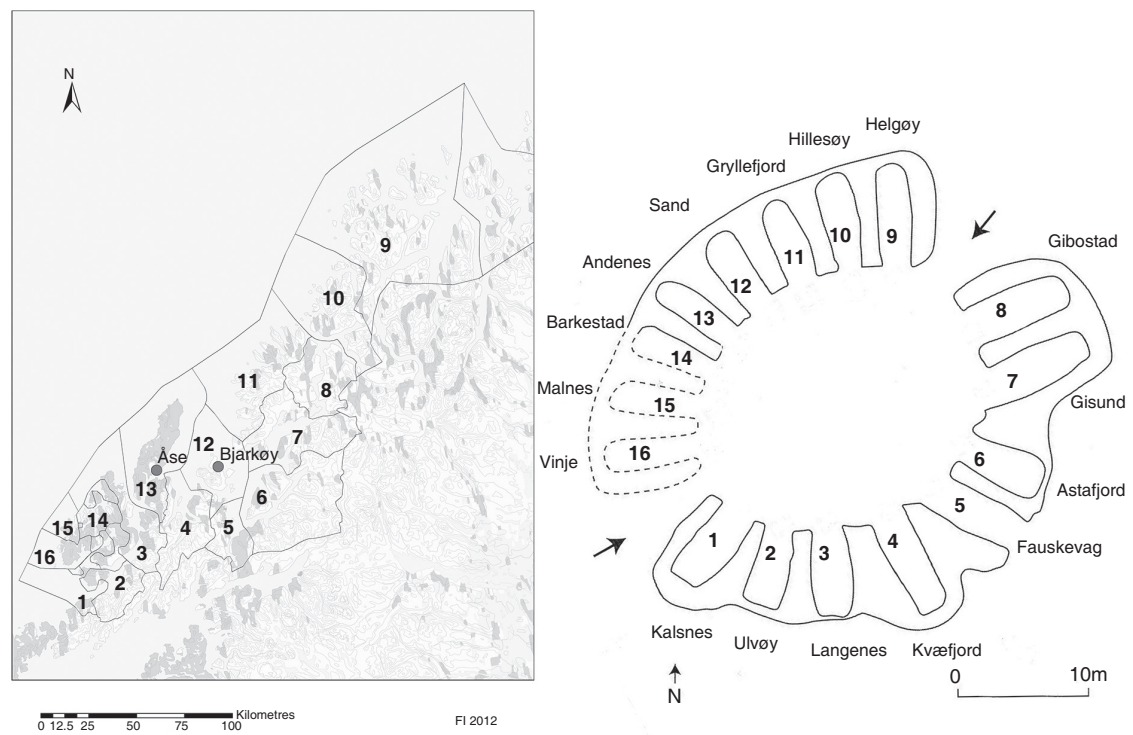

Figure 8.11 The courtyard site at Bjarkøy (6th to 10th centuries) and the surrounding local thingareas (fjerdinger and tingsted) in Vesterålen, Andenes, Senja and Troms, recorded in 1567 (Frode Iversen)

amount to $96-112$, and $12-13$ to 192-208. If approximately 200 individuals met, it would give a space of less than 3 square metres per individual, a tight 'fit' when the smallest buildings are taken into account.

What about the areas further south? Is there an equivalent connection between the houseplots and the local thing-areas? Both Leknes and Steigen may have had fifteen or sixteen such houseplots each, even if this is more uncertain in the case of Leknes. The sites seem to have been in use during different periods. How does this correspond with the thing-areas in this part of Hålogaland? There were sixteen thing-districts in Lofoten and Salten in AD 1557. About $150-180 \mathrm{~km}$ of sea-lane separate the boundary of Salten (Kunna and Gildeskål) in the south from Leknes, depending upon whether the fjord is crossed at Landegode or further north. From Bjerkvik, located at the north-eastern bay of the Ofotfjord, it is $175 \mathrm{~km}$ to Leknes, which, accordingly, was located centrally for this area. I interpret this in the following way: representatives from the areas of Gildeskål, Salten, Bodø, Folda, Leiranger, Engeløy, Hammarøy, Tjeldsund, Ofoten, Lødingen, Våge, Sand, Buksnes, Ramberg and Røst met at Leknes during the early Iron Age. However, it is uncertain whether Ofoten had any Norse population at such an early date. ${ }^{85}$ The site of assembly was relocated to Steigen during the late Iron Age for reasons unknown. The latter was probably more centrally located for the area as a whole, perhaps after Ofoten was included (Figure 8.12). The circumference of this courtyard site

${ }^{85}$ Andersen, 'Ofuohtagat'. 


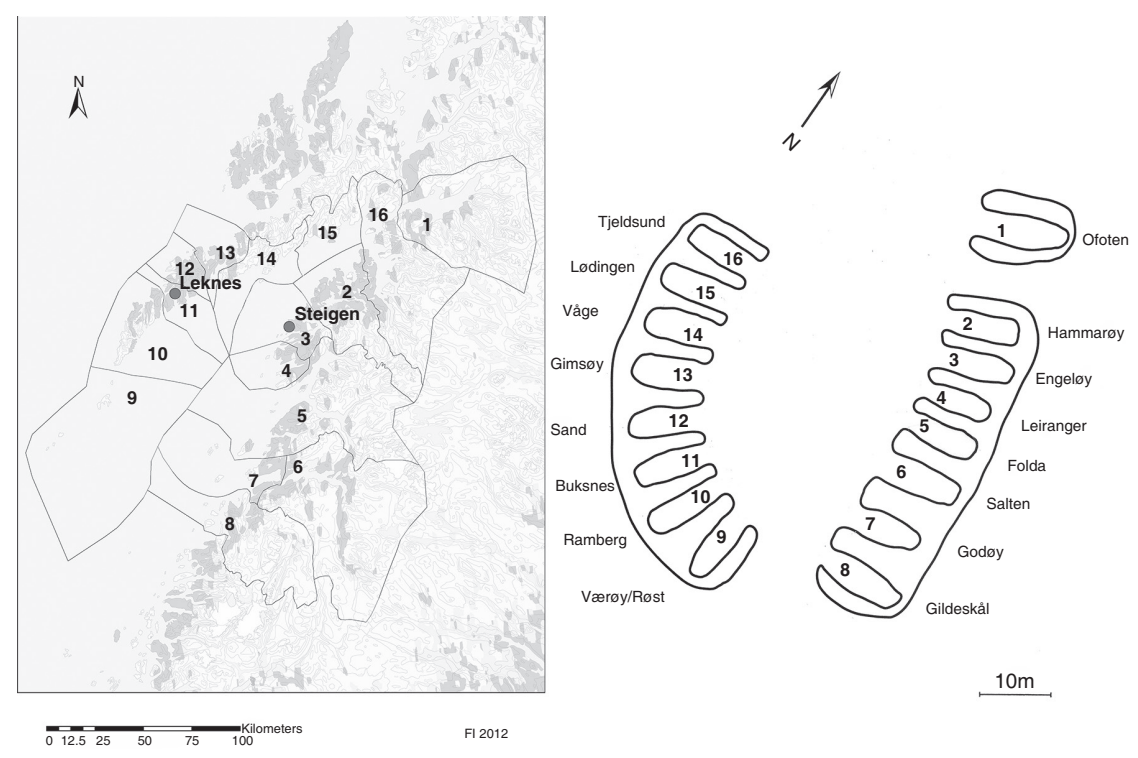

Figure 8.12 The courtyard site at Steigen (6th to 10th centuries) and the surrounding local thingareas (quarters) in Salten and Lofoten, recorded in 1567 (Frode Iversen)

is also larger, and covers an area of 2500 square metres as opposed to 1900 square metres. It is also worth noting that the law-thing of Hålogaland was located in Steigen during the Middle Ages. ${ }^{86}$

The four examples in two main areas of Hålogaland that I have reviewed reveal a close consistency between number of houses and thing-circuits. Similar patterns can also be observed for Rogaland in Southern Norway. The Øygarden site with its ten houseplots abandoned in the 8th century forms a central place for the peripheral parts of Ryfylke, which consisted of ten local thing-areas in the 12 th century. ${ }^{87}$

\section{Conclusions and Perspectives}

My analysis has achieved different results to that of Inger Storli, but we agree that courtyard sites were an early form of legal assembly site. My contribution to the discussion is to include the administrative landscape of the Middle Ages in a contextual framework. It seems clear that the functions of individual courtyard sites are indicated by their size and location, and that they could possibly be connected to known administrative areas of a later date. The combination of archaeological

${ }^{86}$ Iversen, 'Hålogaland blir en rettskrets'.

${ }^{87}$ Iversen, 'Community and Society'. 
and historical sources offers an insight that neither provides separately, and facilitates fundamentally new perspectives on the development of the administrative landscape. The evidence presented here suggests a political centralisation process, where smaller units were abandoned as the result of a need for larger units, as Storli has also suggested. Many of the smaller courtyard sites are situated near the important medieval administrative borders, but this has not been discussed in any detail here. The finds presented indicate that Hålogaland had a more extensive administrative structure during the Iron Age than previous research has implied.

An emphasis on administrative geography enables a different outlook from the more traditional chieftain-based models, where courtyard sites have been regarded as barracks for the chieftains' warriors. Communal institutions of agrarian society are rarely presupposed in the chieftain model as presented in traditional Norwegian research. Contrary to this approach, the findings here suggest the contours of a delegation system similar to that of the medieval regional things. The overall shape and layout of the units, especially the standardised width of the houseplots, are expressions of an egalitarian idea, which is consistent with a formalised decision-making process where all local communities have equal influence. The disuse of courtyard sites could hypothetically be linked to the establishment of ship-districts and expanding royal power in Hålogaland. New principal thing-units and special weapon-things that functioned on a ship-district level evolved. Decision-making things of a military character were gathered and held by individuals that had formalised ties to the king. The courtyard sites thus belong to an earlier phase, where local elites had a larger degree of military authority. Over time, administrative developments would have diminished the need for such local military authorities. I see the disuse and abandonment of courtyard sites as an expression of an emerging royal monopoly of violence in Hålogaland, where military functions were gathered and held by a smaller elite. 